
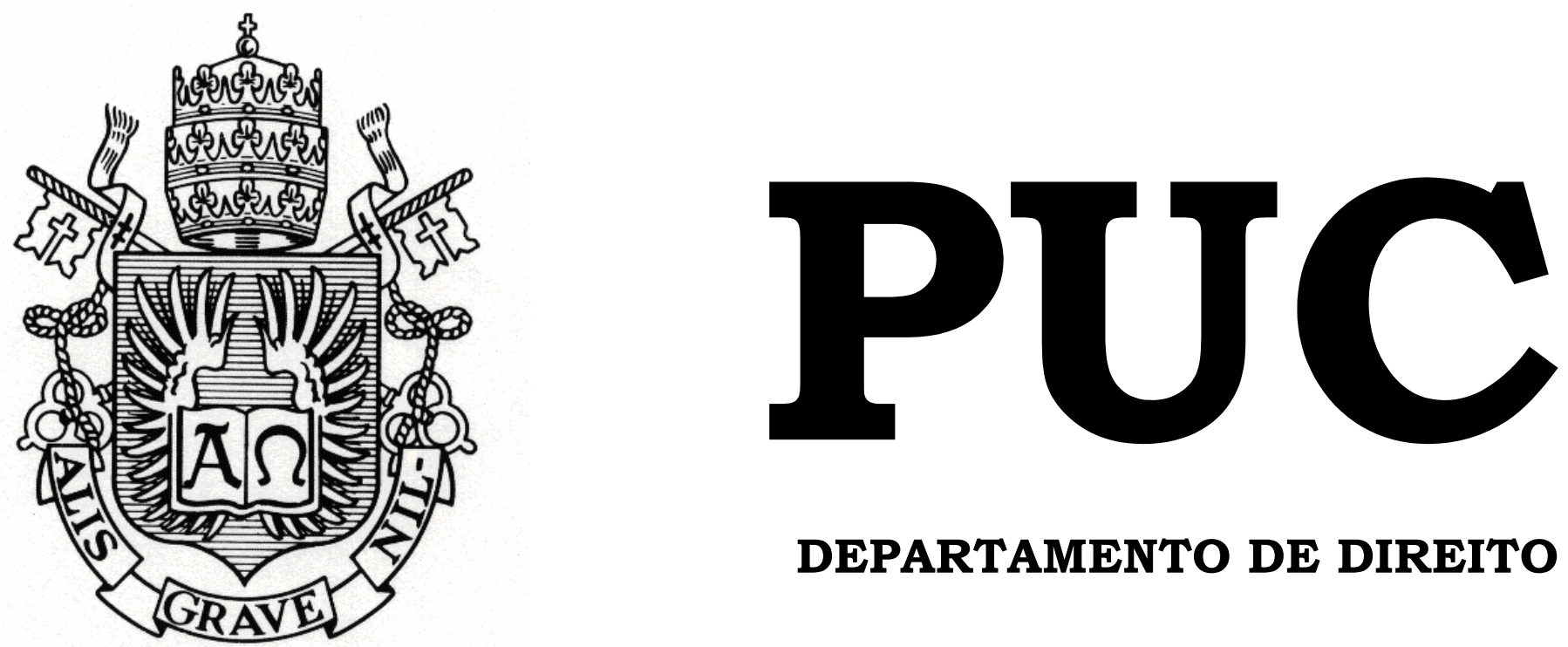

DEPARTAMENTO DE DIREITO

\title{
O FUNDO INSTITUÍDO PELA LEI No 11.079/04 - LEI DAS PARCERIAS PÚBLICO-PRIVADAS - E O REGIME DOS BENS PÚBLICOS
}

por

DEBORAH BLANK

ORIENTADOR: Adriano Pilatti

2005.1

PONTIFÍCIA UNIVERSIDADE CATÓLICA DO RIO DE JANEIRO RUA MARQUÊS DE SÃO VICENTE, 225 - CEP 22453-900 RIO DE JANEIRO - BRASIL 


\title{
O FUNDO INSTITUÍDO PELA LEI No 11.079/04 - LEI DAS PARCERIAS PÚBLICO-PRIVADAS - E O REGIME DOS BENS PÚBLICOS
}

\author{
por \\ DEBORAH BLANK
}

Monografia

apresentada

ao

Departamento de Direito da Pontificia Universidade Católica do Rio de Janeiro (PUC-Rio) para a obtenção do Título de Bacharel em Direito.

Orientador: Adriano Pilatti

2005.1 


\section{Agradecimentos}

À minha família e, em especial, ao meu pai, minha mãe, meu irmão e minha irmã, por todo o apoio, compreensão e paciência.

A Adriano Pilatti, por todos os ensinamentos e aspirações constitucionais, que proporcionaram minha paixão pelo direito público.

A Álvaro Palma de Jorge, por todas as lições de direito e de vida e pelo incentivo e oportunidade de atuação na área do direito constitucional e administrativo, viabilizando um sonho profissional. 


\section{Sinopse}

O tema central do presente trabalho consiste na análise de questões referentes às Parcerias Público-Privadas, aprovadas recentemente pela Lei $n^{\circ} 11.079$, de 30 de dezembro de 2004, com especial enfoque no exame do Fundo Garantidor de Parcerias Público-Privadas - FGP, instituído pela mesma lei com o objetivo de assegurar o cumprimento das obrigações assumidas pela Administração Pública no âmbito desta nova modalidade de contratação administrativa. 


\section{Sumário}

Capítulo 1 - Introdução

6

Capítulo 2 - Parcerias no Brasil

2.1 - As Privatizações

9

2.2 - Disciplina dos Contratos Administrativos Antes da Lei das PPPs 20

Capítulo 3 - As Parcerias Público-Privadas Brasileiras 26

Capítulo 4 - O Fundo Garantidor das PPPs no Âmbito Federal

4.1 - Principais Características do Fundo Garantidor de Parcerias PúblicoPrivadas - FGP

4.2 - A Instituição do FGP e a Constituição de 1988

4.3 - O Patrimônio de Constituição do FGP e sua Natureza Privada 49

Capítulo 5 - Conclusão 71

Referências Bibliográficas 


\section{Introdução}

O presente estudo abordará questões referentes ao novo instituto de contratação administrativa denominado Parceria Público-Privada (“PPP”), instituído recentemente pelo Congresso Nacional através da Lei $n^{\circ} 11.079$, publicada em 30 de dezembro de 2004 (“Lei”).

Faz-se mister destacar que as PPPs brasileiras - assim como ocorreu em diversos países europeus e nos Estados Unidos - surgem após o esgotamento do Estado Social, quando se percebeu a ineficiência da concentração de diversos segmentos sociais e econômicos no seu rol de atribuições, dentre eles a prestação de serviços públicos.

Nesse contexto, foi iniciada, na década de 1990, a onda de privatizações no Brasil, a qual assumiu diversas formas, merecendo destaque, no âmbito do presente estudo, a delegação da execução de serviços públicos a particulares, através de instrumentos como a concessão e a permissão, regidas pela Lei $n^{\circ}$ 8.987, de 13 de fevereiro de 1995 ("Lei de Concessões") e pela Lei no 9.074, de 07 de julho de 1995.

Em complementação aos tradicionais instrumentos de outorga de 
serviços públicos mencionados no parágrafo anterior, a Lei das PPPs é inserida no ordenamento jurídico pátrio como mais um mecanismo de desafogamento do Estado, visando proporcionar ao particular - e aí consiste, a meu ver, a principal inovação do modelo - a segurança de retorno dos investimentos despendidos em empreendimentos que, inicialmente, pertenciam à esfera de competência do ente estatal.

Nesse sentido, a Lei das PPPs busca inovar na forma de atração de investidores para o setor dos serviços públicos e demais contratações administrativas, prevendo o aporte de recursos públicos em projetos que não se sustentem apenas com a cobrança de tarifa, bem como instrumentos de garantia que proporcionem maior segurança ao parceiro privado no que concerne às obrigações assumidas pela Administração Pública.

No que se refere às garantias, o texto legal autoriza, no âmbito federal, a criação de um fundo de natureza privada e sujeito de direitos e obrigações próprios, que garantirá as obrigações assumidas pelo parceiro público. Caso este não honre os compromissos assumidos, o particular poderá executar a garantia prestada pelo fundo, que, por sua vez, cobrará o crédito da Administração Pública contratante para a recomposição de seu patrimônio e, conseqüentemente, a assunção de obrigações referentes a outros contratos de PPP.

Tendo em vista o objetivo primordial da Lei das PPPs, qual seja, a concessão de maiores garantias ao particular para o incremento do setor de serviços públicos, consideramos de extrema relevância um estudo mais aprofundado acerca do fundo garantidor autorizado pelo referido diploma legal, a fim de se verificar a sua viabilidade em face dos preceitos constitucionais e do regime dos bens públicos vigentes no ordenamento pátrio. 
Ressalte-se ainda a importância do referido estudo pelo fato de que o Governo Federal, com base no Plano Plurianual relativo ao período de 2004 a 2007, já disponibilizou a "I Carteira de Projetos de PPP", projetos estes destinados ao desenvolvimento dos setores rodoviário, ferroviário, portuário e de irrigação.

No mesmo sentido, tem-se notícia de que o Governo Federal está trabalhando para dar início aos primeiros projetos de PPP, o que reforça a importância da análise do tema aqui apresentado, a fim de se evitar que eventuais contratos celebrados venham a sofrer alterações substanciais que modifiquem, inclusive, o seu equilíbrio econômico-financeiro.

Como se verá ao longo do presente trabalho, uma vez verificada a inviabilidade da constituição do fundo garantidor instituído pela Lei $\mathrm{n}^{\circ}$ 11.079/04, restará prejudicado o próprio instituto das PPPs tal como idealizado pelo legislador ordinário, o que certamente inibirá a participação dos investidores privados.

No primeiro capítulo, faremos uma breve exposição do cenário anterior à publicação da Lei $\mathrm{n}^{\circ} 11.079 / 04$, sendo o segundo capítulo destinado à abordagem das principais características dos contratos de PPP. Feitas tais considerações, o tema central será abordado no terceiro capítulo, ocasião em que se fará um estudo mais aprofundado sobre o fundo garantidor das PPPs em face do regime dos bens públicos. 
2

\section{Parcerias no Brasil}

\section{1}

\section{As Privatizações}

Após a Segunda Grande Guerra, com o esgotamento do liberalismo, consolidou-se o Estado Social, também conhecido como Estado do BemEstar. As reações contra o Estado Liberal tiveram início em meados do século XIX, quando ficaram evidentes as conseqüências trazidas pelo referido modelo, principalmente no âmbito econômico e social. A formação dos grandes monopólios, em detrimento das empresas de pequeno e médio porte, bem como as condições miseráveis do proletariado refletiam o fracasso da ideologia que justificara o Estado Liberal, baseada principalmente na proteção da liberdade ${ }^{1}$.

Sobre a crise do Estado Liberal, destacamos, desde logo, os ensinamentos de Diogo de Figueiredo Moreira Neto

"Com efeito, como o liberalismo clássico havia mantido o Estado como simples espectador dos fenômenos

\footnotetext{
${ }^{1}$ Nesse sentido, Maria Sylvia Zanella Di Pietro in Parcerias na Administração Pública, $4^{\mathrm{a}}$ edição, Ed. Atlas, 2002, p. 20.

${ }_{2}^{2}$ MOREIRA NETO, Diogo de Figueiredo, Curso de Direito Administrativo, $14^{\mathrm{a}}$ edição, Ed. Forense, 2005, p. 18.
} 
econômicos e sociais, se havia aberto um espaço anômico, que permitiu o crescimento de pólos de poder irrefreados na sociedade, que passaram a causar distorções econômicas e sociais e a comprometer a igualdade de oportunidades entre os indivíduos. Nessas condições, o Estado foi chamado a intervir para coibir os excessos e, ao mesmo tempo, para suprir lacunas abertas pela iniciativa privada, ausente ou insuficiente, para garantir e, posteriormente, dirigir o desenvolvimento econômico."

Nesse contexto, surge uma nova concepção de Estado, através da qual a finalidade última da atuação estatal desloca-se da liberdade para a igualdade. $\mathrm{O}$ Estado deveria promover a igualdade entre os cidadãos, o que somente seria viável a partir da intervenção na ordem econômica e social. Enquanto que no Estado Liberal a preocupação central girava em torno da proteção das liberdades individuais, no Estado Social o principal objetivo seria a preservação do bem comum.

A esse respeito, vale transcrever as lições de Maria Sylvia Zanella Di Pietro $^{3}$ :

"Consolida-se, após a Segunda Guerra Mundial, o Estado Social, também chamado Estado do Bem-Estar, Estado Providencia, Estado do Desenvolvimento, Estado Social de Direito. Não mais se pressupõe a igualdade entre os homens, conforme se afirmava no periodo anterior, quando a Declaração de Direitos do Homem e do Cidadão, de 1789, afirmava, logo no art. $1^{\circ}$, que 'os

\footnotetext{
${ }^{3}$ DI PIETRO, Maria Sylvia Zanella, Parcerias na Administração Pública, $4{ }^{\mathrm{a}}$ edição, Ed.Atlas, 2002, p. 20.
} 
homens nascem e são livres e iguais em direitos'; a aplicação dessa norma produzira profundas desigualdades sociais. Atribui-se então ao Estado, em sua nova concepção, a missão de buscar essa igualdade; para atingir essa finalidade, o Estado deve intervir na ordem econômica e social para ajudar os menos favorecidos; a preocupação maior desloca-se da liberdade para a igualdade."

Assim foi que o Estado, em sua nova roupagem, ampliou significativamente o rol de suas competências, assumindo, dentre outras, as seguintes atribuições: (i) prestação de serviços públicos, o que gerou a criação de novas entidades da administração indireta; (ii) intervenção no domínio econômico, através da regulação e de sociedades de economia mista e empresas púbicas exploradoras de atividade econômica; e (iii) fomento à iniciativa privada no que se refere àquelas atividades não definidas como serviços públicos, nem exercidas pelo Estado a título de intervenção no domínio econômico ${ }^{4}$.

Outra mudança verificada com o advento do Estado Social foi a ampliação do seu poder de polícia. Este não mais se limitou a restringir direitos individuais em benefício da ordem pública, mas passou a ter influência em todos os setores da vida social, inclusive impondo deveres positivos em face dos cidadãos - leia-se obrigações de fazer ${ }^{5}$.

Não obstante a tentativa de se promover a igualdade — tão almejada desde antes da Declaração de Direitos do Homem e do Cidadão, de 1789 —, o crescimento desmesurado do Estado trouxe conseqüências negativas. Com a ampliação das estruturas administrativas a fim de possibilitar a

\footnotetext{
${ }^{4}$ Nesse sentido, Maria Sylvia Zanella di Pietro in Parcerias na Administração Pública, $4{ }^{\mathrm{a}}$ edição, Ed. Atlas, 2002, p. 21.

${ }^{5}$ Nesse sentido, Maria Sylvia Zanella di Pietro in Parcerias na Administração Pública, $4^{\mathrm{a}}$ edição, Ed. Atlas, 2002, p. 22-23.
} 
execução de todas as atividades concentradas no domínio estatal, verificouse o aumento excessivo da burocracia, que acabou por conduzir o Estado à ineficiência na prestação dos serviços públicos.

Nesse sentido, Hely Lopes Meirelles ${ }^{6}$ :

"O crescimento desmesurado da máquina administrativa, com a criação excessiva de empresas públicas, sociedades de economia mista e fundações, além de assunção de atividades privadas que nada tinham a ver com os interesses da coletividade, tornaram o Estado praticamente ingovernável, sem possibilidade de efetivo controle interno finalístico. Ao mesmo tempo, com as modificações ocorridas no campo econômico, foi o Estado perdendo progressivamente a sua capacidade de investimento na infra-estrutura, comprometendo a qualidade dos serviços públicos e, conseqüentemente, atrasando o desenvolvimento do País. Daí por que alguns autores já vinham preconizando a 'reengenharia' do Estado, de forma a reduzir o seu papel e obter maior eficiência no exercício das suas atividades básicas."

De outro lado, para que o Estado pudesse atuar como prestador de serviços, empresário e investidor, foram conferidas ao Poder Executivo amplas atribuições normativas, o que permitiu o seu excessivo fortalecimento e, conseqüentemente, a sua atuação em desconformidade com o princípio da separação dos poderes. Pelo mesmo motivo, verificou-se a extensão do princípio da legalidade, que passou a abranger, além das leis, os atos emanados do Executivo, tais como decretos e portarias.

\footnotetext{
${ }^{6}$ MEIRELLES, Hely Lopes, Direito Administrativo Brasileiro, $30^{\mathrm{a}}$ edição, Ed. Malheiros, 2005, p. 754.
} 
Em conseqüência desse crescimento exacerbado do Estado, seu papel passou por novas transformações. À concepção de Estado de Direito, protetor das liberdades individuais, e de Estado Social, protetor do bem comum, foi incorporado o conceito de Estado Democrático, com enfoque na participação da coletividade no processo político e nas decisões do Governo.

Nessa perspectiva, ressalta Diogo de Figueiredo Moreira Neto ${ }^{7}$ a importância da participação popular para a evolução do Estado:

"Entre o dirigismo estatal e o
individualismo absoluto, parecem
abrir-se, neste início de século, as
alternativas do pluralismo nos campos
econômico e social, exigindo-nos
incorporá-lo também as nossas
instituições políticas, através do
aquecimento da vida democrática,
afirmando-se, no processo, não apenas
um princípio de participação, a
orientá-lo, mas um Direito da
Participação, como esgalhamento
promissor do Direito Politico."

Some-se a este novo arranjo estatal a idéia de Estado Subsidiário, fortalecida com a verificação da ineficiência do Estado Social na prestação dos serviços públicos e na execução das demais atividades de intervenção na ordem econômica e social, como visto acima.

Segundo tal concepção, o Estado deveria abster-se de exercer as atividades que a iniciativa privada pode desempenhar, sempre com o intuito de garantir aos administrados a prestação mais adequada dos serviços de

\footnotetext{
${ }^{7}$ MOREIRA NETO, Diogo de Figueiredo, Curso de Direito Administrativo, $14^{\mathrm{a}}$ edição, Ed. Forense, 2005, p. 19.
} 
que necessitam. Pelo mesmo motivo, a intervenção estatal no domínio econômico deveria sofrer uma limitação, passando o Estado a cuidar apenas da fomentação e fiscalização do setor privado, de modo a proporcionar-lhe condições favoráveis ao sucesso de seus empreendimentos.

Outra idéia ligada ao Estado Subsidiário refere-se à parceria entre público e privado para a prestação dos serviços públicos e atividades não inseridas propriamente nesta categoria, mas que se caracterizam como relevantes para o interesse público ${ }^{8}$.

As inovações na forma de atuação estatal trazidas pela concepção de Estado Subsidiário encontram respaldo no que a doutrina convencionou chamar de princípio da subsidiariedade. A esse respeito, vale destacar, mais uma vez, os ensinamentos da professora Maria Sylvia Zanella Di Pietro':

"Algumas idéias são inerentes ao princípio da subsidiariedade: de um lado, a de respeito aos direitos individuais, pelo reconhecimento de que a iniciativa privada, seja através dos indivíduos, seja através das associações, tem primazia sobre a iniciativa estatal; em consonância com essa idéia, o Estado deve abster-se de exercer atividades que o particular tem condições de exercer por sua própria iniciativa e com seus próprios recursos; em conseqüência, sob esses aspecto, o princípio implica uma limitação à intervenção estatal. De outro lado, o Estado deve fomentar, coordenar, fiscalizar a iniciativa privada, de tal modo a permitir aos particulares, sempre que possível, o

\footnotetext{
${ }^{8}$ Nesse sentido, Arnoldo Wald, Luiza Rangel de Moraes e Alexandre de M. Wald in O Direito de Parceria e a Lei de Concessões, $2^{\mathrm{a}}$ edição, Ed. Saraiva, 2004, p. 31.

${ }^{9}$ DI PIETRO, Maria Sylvia Zanella, Parcerias na Administração Pública, 4a edição, Ed.Atlas, 2002, p. 27.
} 
sucesso na condução de seus empreendimentos. E uma terceira idéia ligada ao principio da subsidiariedade seria a de parceria entre público e privado, também dentro do objetivo de subsidiar a iniciativa privada, quando ela seja deficiente."

No mesmo sentido, assevera Diogo de Figueiredo Moreira Neto ${ }^{10}$ :

"Essa tendência [relativa ao princípio da subsidiariedade] está caracterizada pela preocupação do legislador em aliviar o Poder Público da execução de tarefas de exploração econômica, que possam ser, mais exitosamente, realizadas pelo setor privado, uma orientação que foi acolhida no ordenamento constitucional brasileiro, com a explicitação dos principios do primado da livre iniciativa (arts. $1^{\circ}$, IV e 170, caput) e da limitação interventiva geral às funções de fiscalização, incentivo e planejamento (art. 174, caput)."

Com efeito, algumas atitudes adotadas pelos Estados durante as décadas de 80 e 90 decorreram da aplicação do princípio da subsidiariedade, como forma de diminuir o tamanho da máquina estatal e torná-la mais eficiente.

O regime adotado pela Constituição de 1988 reflete esta tendência. Já no artigo $1^{\circ}$ do texto constitucional, verifica-se a adoção dos valores sociais da livre iniciativa como um dos fundamentos da República Federativa do Brasil.

\footnotetext{
${ }^{10}$ MOREIRA NETO, Diogo de Figueiredo, Curso de Direito Administrativo, $14^{\mathrm{a}}$ edição, Ed. Forense, 2005, p. 436.
} 
Mais adiante, a Carta Magna, em seu art. 170, caput, estabelece que a ordem econômica se funda na livre iniciativa, que, em razão da preocupação do constituinte originário com os seus valores sociais, deve encontrar limite na realização da justiça social, privilegiando o desenvolvimento do setor privado conforme as diretrizes estabelecidas pelo Poder Público. Daí por que ensina José Afonso da Silva ${ }^{11}$ que a liberdade de iniciativa privada "será ilegítima, quando exercida com objetivo de puro lucro e realização pessoal do empresário".

De acordo com a Constituição da República, o Estado pode atuar no cenário econômico de três formas: (i) como agente normativo e regulador, nos termos do artigo 174; (ii) como explorador de atividade econômica, em igualdade de condições com a iniciativa privada, nos casos excepcionais previstos no artigo 173 - quando necessário aos imperativos da segurança nacional ou a relevante interesse público; e (iii) como explorador de atividade econômica exercida em caráter de monopólio, tal como previsto nos artigos 176 e 177.

Quanto aos serviços públicos, a Constituição Federal também reflete a influência do princípio da subsidiariedade. Assim é que, nos termos do artigo 175, "incumbe ao poder público, na forma da lei, diretamente ao sob regime de concessão ou permissão, sempre através de licitação, a prestação dos serviços públicos." (grifos acrescentados)

Note-se que tanto o Estado, diretamente, quanto o particular, por meio de delegação do Poder Público — através de concessão ou permissão -, estão autorizados a prestar os serviços públicos, o que denota a preocupação da Carta Política de 1988 em conferir maior eficiência à execução de tais atividades.

\footnotetext{
${ }^{11}$ DA SILVA, José Afonso, Curso de Direito Constitucional Positivo, 22 $22^{\mathrm{a}}$ edição, Ed. Malheiros, 2003, p. 770 .
} 
Ainda em relação à influência da concepção de Estado Subsidiário nos modelos de Estado atuais, outra evidência foi a onda de privatizações verificada na década de 1990. Nesse sentido, leciona Maria Sylvia de Pietro $^{12}$ que três aspectos motivaram a ocorrência de tal fenômeno: o financeiro, "pelo intuito de diminuir os gastos públicos com empresas estatais deficitárias, de cujos riscos financeiros o Estado participa"; o jurídico, "pela necessidade de retornar a formas de gestão privada dos serviços públicos, sem os controles excessivos e os formalismos próprios da Administração centralizada"; e o político, "pela presença da inspiração neoliberal, que aconselha a substituição do Estado pela iniciativa privada, por ser ela mais apta a gerir atividades comerciais e industriais".

Faz-se oportuno destacar ainda que a extensão do conceito de privatização não constitui matéria pacífica entre os doutrinadores, seja no ramo do Direito, seja no campo das ciências políticas e econômicas. Enquanto alguns autores como Eros Roberto $\mathrm{Grau}^{13}$ defendem a utilização restrita do conceito, outros como Maria Sylvia Zanella Di Pietro ${ }^{14}$ preferem atribuir ao termo maior amplitude.

Segundo entendimento da primeira corrente, a expressão privatização deve se limitar aos casos de transferência do controle acionário de empresas estatais a particulares.

De outro lado, entende a segunda corrente que o conceito deve abranger todas as ações estatais possíveis com o objetivo de reduzir a

\footnotetext{
${ }^{12}$ DI PIETRO, Maria Sylvia Zanella, Parcerias na Administração Pública, $4^{\mathrm{a}}$ edição, Ed. Atlas, 2002, p. 29.

${ }^{13}$ Conforme citado por Thereza Maria Sarfert in Técnicas de Privatização, Revista de Direito Mercantil, Industrial, Econômico e Financeiro, no 117, p. 215. "Eros Roberto Grau, em sala de aula, seguindo Washington Peluso Albino de Souza, critica a imprecisão terminológica legal, que não diferencia 'privatização' de 'desestatização'. A expressão 'privatização', para ambos, estaria limitada à sua compreensão original, isto é, à transferência de controle acionário de empresas estatais para particulares. [...]"
} 
participação do Estado em alguns setores estratégicos e prestigiar a iniciativa privada e os modos privados de gestão. Assim, poder-se-ia elencar como técnicas de privatização as seguintes ${ }^{15}$ :

(i) desregulação, com a redução do intervencionismo estatal nas atividades privadas;

(ii) desmonopolização de atividades econômicas, com a abertura à iniciativa privada de setores anteriormente explorados pelo poder público;

(iii) transferência de controle de empresas públicas e sociedades de economia mista e de bens públicos a particulares;

(iv) concessão de serviços públicos;

(v) parcerias do setor público com o privado;

(vi) contratação, por parte da Administração Pública, de serviços de entidades privadas, também conhecida como contracting out, categoria na qual se inserem os contratos de obras e prestação de serviços, bem como as terceirizações; e

(vii) adoção de técnicas de gestão de natureza privada em empresas estatais.

Convém destacar que as ações elencadas acima representam as técnicas de privatização mais utilizadas, o que não exclui a possibilidade de que outras venham a ser adotadas pelo Estado. Esta é justamente a vantagem da posição doutrinária ora em comento.

${ }^{14}$ In Parcerias na Administração Pública, 4 a edição, Ed. Atlas, 2002, p. 17-20.

${ }^{15}$ Sistematização baseada na concepção de Maria Sylvia Zanella di Pietro in Parcerias na Administração Pública, $4^{\mathrm{a}}$ edição, Ed. Atlas, 2002, p. 17-20; e Thereza Maria Sarfert in Técnicas de Privatização, Revista de Direito Mercantil, Industrial, Econômico e Financeiro, no 117, p. 215216. 
Ressalte-se que foi nesse contexto de privatização - ou desestatização - que se verificou o marco legal do regime de contratação pública no Brasil, instituído, de um lado, pela Lei $n^{\circ}$ 8.666/93, com a sistematização das normas gerais sobre licitações e contratos administrativos, e, de outro, pelas Leis $n^{\circ} \mathrm{s} 8.987 / 95$ e 9.074/95, com regras específicas para as concessões de serviços públicos, das quais, como se verá adiante, constituem modalidades as Parcerias Público-Privadas.

A base constitucional dos referidos diplomas legais está prevista no artigo 175 , exposto acima, que autoriza a delegação dos serviços públicos à iniciativa privada. Feito este breve histórico, passaremos à análise dos principais aspectos do regime jurídico dos contratos administrativos antes do advento da Lei das PPPs. 


\section{2}

\section{Disciplina dos Contratos Administrativos Antes da Lei das PPPs}

Conforme citado no item anterior, antes da instituição das PPPs, com o advento da Lei $n^{\circ} 11.079 / 04$, a disciplina da contratação administrativa no Brasil era regida basicamente pela Lei $n^{\circ}$ 8.666, de 21 de junho de 1993 ("Lei de Licitações") e Lei no 8.987, de 13 de fevereiro de 1995, com as especificações trazidas pela Lei no 9.074, de 07 de julho de 1995.

Referidas leis foram editadas em conformidade com o disposto no artigo 22, XXVII, da Constituição da República, segundo o qual compete à União estabelecer normas gerais sobre licitações e contratos administrativos aplicáveis a todas as esferas da federação, reservando-se aos Estados, Distrito Federal e Municípios, a competência para instituir normas específicas sobre o tema.

Nesse sentido, é importante destacar que as regras contidas nas leis acima mencionadas, na medida em que extrapolem a competência determinada pela Constituição, serão aplicáveis somente no nível federal, 
sob pena de se agredir o princípio federativo, elevado à cláusula pétrea pela Carta Política de $1988^{16}$.

Sobre o regime jurídico anterior à edição da Lei $n^{0} 11.079 / 04$, note que as modalidades de contratação pública podiam ser divididas em dois grandes grupos: de um lado, a concessão e a permissão de serviços públicos, regidas pelas Leis nº n $^{\circ} .987 / 95$ e 9.074/95; e, de outro, os demais contratos administrativos não caracterizados como concessão, regidos pela Lei $n^{\circ} 8.666 / 93$.

É importante destacar que o advento de legislação específica para regular os contratos de concessão e permissão não afastou a aplicação subsidiária da Lei de Licitações aos referidos instrumentos e respectivos certames licitatórios, sendo aplicável, por óbvio, apenas os dispositivos que sejam compatíveis com o regime instituído pela Lei no 8.987/95.

Não obstante a distinção feita acima acerca dos dois modelos contratuais, faz-se mister comentar algumas características próprias do regime jurídico dos contratos administrativos em geral, comuns, portanto, tanto aos contratos de concessão e permissão de serviços públicos quanto aos contratos regidos pela Lei $n^{\circ} 8.666 / 93$.

Dentre as principais características, merece destaque a que se refere às prerrogativas especiais da Administração Pública em face do particular, o que permite definir a relação estabelecida entre os contratantes como vertical.

\footnotetext{
${ }^{16}$ Sobre o princípio federativo como cláusula pétrea, vide o disposto no artigo $60, \S 4^{\circ}$, I, da Constituição de 1988. No que se refere à limitação da competência da União para instituir normas gerais, vide a decisão liminar proferida pelo Supremo Tribunal Federal nos autos da Ação Direta de Inconstitucionalidade ${ }^{\circ}$ 927-3/RS, na qual foi suspensa a aplicação do artigo 17, I, c, da Lei de Licitações, aos Estados e Municípios, por entender a Egrégia Corte que o referido dispositivo não possui caráter de norma geral.
} 
A esse respeito, observe-se as lições de Celso Antônio Bandeira de Mello ${ }^{17}$ :

"É de notar que as prerrogativas em pauta colocam o 'contrato' à mercê de umas das partes, tanto no que atina à continuidade quanto, dentro de certos limites, no que respeita às condições relativas à prestação devida pelo particular. Dai que subvertem profundamente a noção de contrato encontradiça na teoria geral do Direito, autorizando a questionar se ainda seria o caso de usar com propriedade esta titulação. A qualificação 'administrativo' aposta à palavra 'contrato' parece, no caso, ter $o$ condão de modificar o próprio sentido substantivo."

Seja por força de disposição legal, seja por força de cláusulas contratuais expressas, o poder público contratante assume posição de vantagem, podendo, inclusive, modificar unilateralmente as obrigações pactuadas no contrato, bem como rescindi-lo sem a necessidade de anuência da outra parte.

Estes são exemplos do que a doutrina convencionou chamar de cláusulas exorbitantes, previstas no artigo 58 da Lei de Licitações, conforme transcrição a seguir:

"Art. 58. O regime jurídico dos contratos administrativos instituido por esta Lei confere à Administração, em relação a eles, a prerrogativa de: I- modificá-los, unilateralmente, para melhor adequação às finalidades de

\footnotetext{
${ }^{17}$ BANDEIRA DE MELLO, Celso Antônio, Curso de Direito Administrativo, $17^{\mathrm{a}}$ edição, Ed. Malheiros, 2004, p. 569.
} 
interesse público, respeitados os direitos do contratado;

II - rescindi-los, unilateralmente, nos casos especificados no inciso I do art. 79 desta Lei;

III - fiscalizar-lhes a execução;

IV - aplicar sanções motivadas pela inexecução total ou parcial do ajuste;

$V$ - nos casos de serviços essenciais, ocupar provisoriamente bens móveis, imóveis, pessoal e serviços vinculados ao objeto do contrato, na hipótese de necessidade de acautelar apuração administrativa de faltas contratuais pelo contratado, bem como na hipótese de rescisão do contrato administrativo. $[\ldots]^{\prime \prime}$

Quanto à verticalidade da relação contratual em comento, ensina Diogo de Figueiredo Moreira Neto ${ }^{18}$ que os contratos regidos pela Lei $n^{0}$ 8.666/93, bem como os contratos de concessão e de permissão, "são aqueles nos quais o interesse público específico a ser atingido é um interesse administrativo primário, casos em que está plenamente investida a Administração Pública das prerrogativas expressas em seu regime jurídico próprio".

Obviamente, o uso de tais prerrogativas deverá ser autorizada por alguma espécie de descumprimento contratual pelo particular, por razões de interesse público ou, ainda, por motivos de caso fortuito ou força maior. Outra garantia conferida ao contratante privado é o seu direito ao equilíbrio econômico-financeiro do contrato durante toda a sua vigência ${ }^{19}$. Não fosse

\footnotetext{
${ }^{18}$ MOREIRA NETO, Diogo de Figueiredo, Curso de Direito Administrativo, 14 a edição, Ed. Forense, 2005, p. 174.

${ }^{19}$ Nesse sentido, dispõem os parágrafos $1^{\circ}$ e $2^{\circ}$ ao artigo 58 da Lei de Licitações: “§ $1^{\circ}$ As cláusulas econômico-financeiras e monetárias dos contratos administrativos não poderão ser alteradas sem prévia concordância do contratado. $\S 2^{\circ} \mathrm{Na}$ hipótese do inciso I deste artigo [modificação unilateral do contrato], as cláusulas econômico-financeiras do contrato deverão ser revistas para que se mantenha o equilíbrio contratual."
} 
assim, estariam os contratos administrativos fadados à completa insegurança jurídica.

Em relação às peculiaridades de cada modalidade de contrato administrativo apresentada, note que a concessão e permissão ${ }^{20}$ de serviços públicos são institutos através dos quais o Estado atribui a execução de determinado serviço público a um particular, por sua conta e risco, sob as condições fixadas pela Administração. $O$ retorno financeiro do empreendimento é garantido pela tarifa cobrada do usuário do serviço, sendo possível ainda a aferição de receitas acessórias decorrentes da exploração de projetos associados ${ }^{21}$.

Nesse sentido, Maria Sylvia Zanella Di Pietro ${ }^{22}$ :

"Dai definirmos a concessão de
serviço público como o contrato
administrativo pelo qual a
Administração Pública delega a
outrem a execução de um serviço
público, para que o execute em seu
próprio nome, por sua conta e risco,
mediante tarifa paga pelo usuário ou
outra forma de remuneração
decorrente da exploração do serviço."

Convém lembrar ainda que somente poderá ser outorgada a particulares a execução de serviços públicos tidos como privativos do Estado e cuja prestação não haja sido reservada exclusivamente ao Poder Público, como é o caso do serviço postal e do correio aéreo nacional (artigo 21, X, da Constituição da República).

\footnotetext{
${ }^{20}$ Hoje o instituto da permissão em muito se assemelha ao da concessão, por força do artigo 40 da Lei $\mathrm{n}^{\mathrm{o}} 8.987 / 95$.

${ }^{21}$ Vide artigo 11 da Lei $n^{\circ} 8.987 / 95$.

22 DI PIETRO, Maria Sylvia Zanella, Parcerias na Administração Pública, $4^{\mathrm{a}}$ edição, Ed. Atlas, 2002, p. 75.
} 
No que tange às demais modalidades de contratos administrativos não caracterizados como concessões ou permissões de serviços públicos é possível, a partir do artigo $2^{\circ}$ da Lei $n^{\circ} 8.666 / 93$, distinguir algumas de suas espécies, quais sejam, o contrato de obras, de serviços (inclusive de publicidade), de compra, de alienação e de locação.

Sobre o mencionado dispositivo, duas observações devem ser feitas. Em primeiro lugar, deve-se atentar para a menção a contratos de concessão e permissão, que, em momento posterior à Lei de Licitações, ganharam legislação específica; e, em segundo, para o caráter não exaustivo do mencionado artigo $2^{\circ}$, podendo haver outras modalidades de contratação pública que não as elencadas na referida lei.

Como se verá adiante, com o advento da Lei $n^{0} 11.079 / 04$, foram criadas no direito positivo brasileiro duas novas modalidades de contratos administrativos, na verdade, duas subespécies de contratos de concessão: a concessão patrocinada e a concessão administrativa (artigo $2^{\circ}$ ). 


\section{3}

\section{As Parcerias Público-Privadas Brasileiras}

Em 30 de dezembro de 2004, após mais de um ano de discussão no Congresso Nacional, foi publicada a lei que instituiu as Parcerias PúblicoPrivadas ("PPPs") — Lei n 11.079/04.

Antes de entrar no tema central do presente estudo, qual seja, a viabilidade do fundo garantidor criado pela Lei das PPPs em face do regime dos bens públicos hoje vigente, passaremos a uma breve análise desta nova modalidade de contratação pública.

De acordo com a Lei $\mathrm{n}^{\mathrm{o}} 11.079 / 04$, as PPPs enquadram-se como contratos de concessão, podendo assumir duas modalidades distintas: as concessões patrocinadas ou administrativas.

As concessões patrocinadas possuem como objeto a prestação de serviços públicos, precedida ou não da realização de obra pública, de que trata a Lei $\mathrm{n}^{\circ} 8.987 / 95$, mas que requeiram, além da tarifa cobrada do usuário, contraprestação do parceiro público ao particular. É o que dispõe o parágrafo $1^{\circ}$ do artigo $2^{\circ}$ da Lei das PPPs:

"Art. 2". Parceria público-privada é o contrato administrativo de concessão, 
na modalidade patrocinada ou administrativa.

$\S 1^{\circ}$ Concessão patrocinada é a concessão de serviços públicos ou de obras públicas de que trata a Lei $n^{\circ}$ 8.987, de 13 de fevereiro de 1995 , quando envolver, adicionalmente à tarifa cobrada dos usuários, contraprestação pecuniária do parceiro público ao parceiro privado. [...]."

Trata-se das hipóteses em que o empreendimento não se configura como auto-sustentável, de modo que apenas a cobrança da tarifa não torna o projeto economicamente viável. É o caso, por exemplo, da construção de estradas com pouco movimento.

As concessões administrativas, por sua vez, são definidas como os contratos de prestação de serviços em que a Administração Pública seja usuária direta ou indireta, envolvendo ou não a execução de obras e o fornecimento de bens. Observe-se o disposto no parágrafo $2^{\circ}$ do artigo $2^{\circ}$ da Lei $n^{\circ} 11.079 / 04$ :

"§2o Concessão administrativa é o contrato de prestação de serviços de que a Administração Pública seja a usuária direta ou indireta, ainda que envolva execução de obra ou fornecimento e instalação de bens."

Referem-se, portanto, aos casos em que o parceiro privado preste serviço diretamente ao parceiro público, ou, ainda, às situações em que o serviço seja usufruído diretamente pela coletividade - logo, indiretamente pela Administração - não sendo, porém, cabível a cobrança de tarifa. A construção e operação de presídios ou de hospitais públicos podem ser exemplos deste tipo de parceria. 
Embora a Lei das PPPs enquadre esta modalidade de parceria também como contrato de concessão, não nos parece clara a distinção entre a concessão administrativa e os contratos de prestação de serviços regidos pela Lei ${ }^{0} 8.666 / 93$.

A partir da leitura da Lei $n^{\circ} 11.079 / 04$, não é possível afirmar que as concessões administrativas terão como objeto a prestação de serviços públicos. Como visto acima, a Lei fala apenas em prestação de serviços, de modo que, até que sobrevenha regulamentação específica do Poder Executivo Federal, não se pode afirmar que o enquadramento desta modalidade de PPP como concessão está correto. Nos termos da Lei ${ }^{\circ}$ 8.987/95, somente pode ser objeto de concessão a prestação de serviços públicos ${ }^{23}$.

Sobre o tema, já se percebe posicionamentos distintos entre os autores. Segundo Pedro Raposo Lopes ${ }^{24}$, “as chamadas 'concessões administrativas' nada mais são que pura prestação de serviços à Administração Pública, não se instaurando, por intermédio delas, a relação triangular ínsita às concessões".

E conclui o autor:

"O que a lei optou por chamar de
'concessão administrativa' nada mais
$e ́$ que prestação de serviços sic et
simpliciter, regida, pois, pela Lei $n^{\circ}$
8.666/93."

\footnotetext{
23 "Art. $1^{\circ}$. As concessões de serviços públicos e de obras públicas e as permissões de serviços públicos reger-se-ão pelos termos do art. 175 da Constituição Federal, por esta Lei, pelas normas legais pertinentes e pelas cláusulas indispensáveis dos contratos."

${ }^{24}$ LOPES, Pedro C. Raposo. Público e Privado. PPP é nova modalidade de concessão de serviços públicos. Consultor Jurídico, 12 jan. 2005, p. 2.
} 
Favorável à distinção entre as concessões administrativas e os contratos regidos pela Lei $\mathrm{n}^{\circ} 8.666 / 93$, observe-se o entendimento de José dos Santos Carvalho Filho ${ }^{25}$ :

"Na verdade, a lei ficou confusa quanto ao objeto da concessão administrativa. [...] De logo, fala-se em prestação de serviços sem qualquer especificação quanto à sua natureza. Ademais, diz-se que os serviços se destinam à Administração como usuária direta ou indireta. Mas o que significa ser 'usuário direto ou indireto' do serviço?

$A$ expressão é vaga e de difícil inteligência. Ao que parece a lei pretendeu dar em concessão uma série de atividades tipicamente administrativas, para as quais precisará de investimentos do setor privado. [...] Nota-se, pois, que o sistema pretende admitir a contratação de variada gama de serviços públicos de natureza administrativa, única hipótese em que se pode entender o fato de ser a Administração usuária direta ou indireta desses mesmos serviços.

Conquanto semelhantes em face do mesmo objeto, e ainda que em ambos a Administração seja usuária do serviço, o contrato de concessão administrativa de serviços não tem o perfil idêntico ao do contrato de serviços regulado pela Lei $n^{\circ}$ 8.666/93. Neste, o particular contratado limita-se à prestação do serviço, cabendo à Administração pagar o respectivo preço em dinheiro; naquele, o concessionário presta o serviço mas se lhe exige que faça investimento na atividade, obrigandose a Administração a uma

\footnotetext{
${ }^{25}$ CARVALHO FILHO, José dos Santos, Manual de Direito Administrativo, $13^{\mathrm{a}}$ edição, Ed. Lumen Juris, 2005, p. 327-328.
} 
contraprestação pecuniária que pode variar de espécie, como reza o art. $6^{\circ}$ da Lei $n^{\circ}$ 11.079."

Como se vê, não está clara a distinção entre as concessões administrativas e os contratos de prestação de serviços regidos pela Lei de Licitações, o que somente poderá ser averiguado com a regulamentação do instituto das PPPs e a própria utilização do novo modelo contratual.

Quanto à aplicação das leis que regem as concessões de serviços públicos às PPPs, observe-se o artigo $3^{\circ}$ da Lei $n^{\circ} 11.079 / 04$ :

"Art. 3\%. As concessões administrativas regem-se por esta Lei, aplicando-selhes adicionalmente o disposto nos arts. 21, 23, 25 e 27 a 39 da Lei $n^{\circ}$ 8.987, de 13 de fevereiro de 1995, e no art. 31 da Lei $n^{\circ} 9.074$, de 07 de julho de 1995.

$\S 1^{\circ}$ As concessões patrocinadas regem-se por esta lei, aplicando-selhes subsidiariamente o disposto na Lei $n^{\circ}$ 8.987, de 13 de fevereiro de 1995, e nas leis que lhe são correlatas. $[\ldots] "$

Além dos diplomas legais mencionados acima, aplicam-se subsidiariamente a ambas as modalidades de PPPs as disposições constantes da Lei $\mathrm{n}^{\circ}$ 8.666/93, que estabelece normas gerais para as licitações realizadas em todas as esferas da Administração Pública.

Critérios de Utilização das PPPS

A escolha do modelo contratual apropriado para determinado projeto será definida com base na sua capacidade de geração de receita. Este será o 
fator principal para a análise da necessidade de aporte de recursos públicos no contrato que se pretende formalizar e, conseqüentemente, da adoção do regime das PPPs, mais especificamente, da concessão patrocinada.

No âmbito federal, referido diagnóstico será elaborado pelo Comitê Gestor de Parceria Público-Privada Federal ("CGP"), criado pela Lei $\mathrm{n}^{\circ}$ 11.079/04 e regulamentado pelo Decreto n ${ }^{0} 5.385$, de 04 de março de 2005. Referido órgão analisará ainda (i) o Plano Plurianual, a Lei de Responsabilidade Fiscal e a Lei de Diretrizes Orçamentárias; (ii) o interesse do setor privado; e (iii) o pronunciamento dos Ministérios do Planejamento, Orçamento e Gestão e da Fazenda.

Somente depois de constatada a necessidade da injeção de recursos públicos no projeto, a legalidade do dispêndio financeiro por parte da Administração e a viabilidade da garantia a ser oferecida ao parceiro privado é que poderá ser adotada a estrutura contratual instituída pela Lei ${ }^{\circ}$ $11.079 / 04$.

Nos termos do Decreto $\mathrm{n}^{0} 5.385 / 04$, o CGP será composto por membros do Ministério do Planejamento, Orçamento e Gestão, Ministério da Fazenda e Casa Civil, tendo ainda, em sua Comissão Técnica, a participação de outros ministérios além dos já citados, bem como de integrantes do Banco Nacional de Desenvolvimento Econômico e Social BNDES, Banco do Brasil S.A. e Caixa Econômica Federal (artigos $2^{\circ}$ e 10).

Conforme dispõe o artigo $3^{\circ}$ do supracitado decreto, caberá ao CGP a definição dos empreendimentos prioritários a serem executados em regime de PPP, aprovação dos respectivos editais e contratos, autorização para abertura do procedimento licitatório, sistematização dos procedimentos a serem observados para a assinatura dos contratos e apreciação de seus relatórios de execução. 
Uma vez selecionados os projetos prioritários e aprovados os respectivos editais e contratos pelo CGP, estes últimos serão encaminhados ao Ministério setorial envolvido, para a realização do correspondente certame licitatório.

\section{Principais Características}

Para uma melhor compreensão do fundo garantidor instituído pela Lei ${ }^{\circ} 11.079 / 04$, a ser abordado no próximo capítulo, faz-se oportuna uma breve análise das principais característica das Parcerias Público-Privadas.

A esse respeito, vale ressaltar que, além dos requisitos para a utilização do novo modelo apresentados acima, a Lei das PPPs trouxe outras restrições a fim de evitar o seu uso indiscriminado.

De acordo com o parágrafo $4^{\circ}$ do artigo $2^{\circ}$, o prazo dos contratos deverá ser de, no mínimo, 5 (cinco) e, no máximo, 35 (trinta e cinco) anos, admitida eventual prorrogação ${ }^{26}$, e o valor envolvido nas parcerias não poderá ser inferior a $\mathrm{R} \$ 20.000 .000,00$ (vinte milhões de reais). $\mathrm{O}$ dispositivo legal prevê ainda que os contratos de PPP não poderão ter como objeto, unicamente, o fornecimento de mão de obra, o fornecimento e instalação de equipamento ou a execução de obra pública.

Outra imposição legal está contida no artigo $9^{\circ}$, que tornou obrigatória a constituição de sociedade de propósito específico ("SPE”) para a execução do objeto da parceria, regra facultativa no caso das concessões comuns. Com efeito, tal mecanismo permite um maior controle

\footnotetext{
${ }^{26}$ Vide também o disposto no artigo $5^{\circ}$, I.
} 
sobre o desempenho do parceiro privado no implemento do projeto, uma vez que delimita um único campo de atuação para a empresa contratada.

Nesse sentido, observe-se os ensinamentos de José dos Santos Carvalho Filho $^{27}$ ao comentar a previsão legal que obriga a constituição de SPE:

"Pretendeu o legislador colocar em apartado a pessoa jurídica interessada na parceria, de um lado, e a pessoa jurídica incumbida da execução do objeto do contrato, de outro. A providência, de fato, permitirá melhor forma de controle do poder concedente sobre as atividades, o desempenho e as contas do parceiro privado."

Como forma de atrair o setor privado para a implementação de projetos de PPP, importante inovação da Lei refere-se à repartição objetiva dos riscos do negócio entre as partes contratantes. Tal previsão encontra-se elencada entre as diretrizes para a contratação das parcerias $\left(\operatorname{artigo} 4^{\circ}, \mathrm{VI}^{28}\right)$, sendo certo que representa uma importante diferença em relação às concessões comuns, nas quais os riscos do empreendimento são assumidos integralmente pelo particular.

Sobre o tema, vale citar o ilustre autor Hely Lopes Meirelles ${ }^{29}$ :

$$
\begin{aligned}
& \text { "A Lei } n^{\circ} 11.079 \text {, de } 30.12 .2004 \text {, define } \\
& \text { a parceria público-privada como } \\
& \text { contrato administrativo de concessão, } \\
& \text { mas uma concessão especial, diversa } \\
& \text { da que estudamos anteriormente, }
\end{aligned}
$$

\footnotetext{
${ }^{27}$ CARVAlHO FILHO, José dos Santos, Manual de Direito Administrativo, $13^{\mathrm{a}}$ edição, Ed. Lumen Juris, 2005, p. 333.

${ }^{28}$ Vide também o disposto no artigo $5^{\circ}$, III.

${ }^{29}$ MEIRELLES, Hely Lopes, Direito Administrativo Brasileiro, $30^{\mathrm{a}}$ edição, Ed. Malheiros, 2005, p. 386.
} 
porque o particular presta o serviço em seu nome, mas não assume todo o risco do empreendimento, uma vez que o Poder Público contribui financeiramente para sua realização e manutenção."

Com o intuito de tornar possível o compartilhamento dos riscos do projeto, o regime das PPPs adotou uma nova estrutura de remuneração ao parceiro privado, composta não apenas pela tarifa cobrada do usuário, mas também pelo pagamento devido por parte do Poder Público. Caso o aporte de recursos públicos corresponda a mais de $70 \%$ (setenta por cento) da remuneração, será necessária autorização legislativa específica (artigo 10, $\left.\S 3^{\circ}\right)$.

É importante destacar que a contraprestação pública deverá ser, obrigatoriamente, precedida da disponibilização do serviço, podendo o contrato prever a sua vinculação ao desempenho do particular na execução do objeto da parceria (artigos $7^{\circ}$ e $6^{\circ}$, parágrafo único, respectivamente).

Sendo assim, é fundamental que o financiamento do projeto esteja muito bem estruturado, de modo a viabilizar os dispêndios devidos pelo parceiro privado durante o período de construção do projeto, fase em que, como visto, não será possível o aporte de recursos públicos.

Ainda em relação ao pagamento devido pelo contratante público, permite o artigo $6^{\circ}$ da Lei das PPPs que este seja efetuado mediante ordem bancária, cessão de créditos não tributários, outorga de direitos em face da Administração Pública e sobre bens dominicais, dentre outros meios admitidos em lei.

De acordo com o artigo $8^{\circ}$ do diploma legal em exame, o cumprimento das obrigações oponíveis à Administração Pública poderá ser 
garantido por: (i) vinculação de receitas, observada a proibição de vinculação de impostos prevista na Constituição da República; (ii) fundos especiais; (iii) contratação de seguro-garantia com seguradoras não controladas pelo poder público; (iv) organismos internacionais ou instituições não controladas pela Administração Pública; (v) fundo garantidor ou empresa estatal criada para essa finalidade; e (vi) outros mecanismos admitidos pelo ordenamento jurídico pátrio.

No âmbito federal, a Lei $\mathrm{n}^{\mathrm{o}}$ 11.079/04, em seu artigo 16, autoriza a criação do Fundo Garantidor de Parcerias Público-Privadas ("FGP" ou "Fundo"), "que terá por finalidade prestar garantia de pagamento de obrigações pecuniárias assumidas pelos parceiros públicos federais em virtude das parcerias [...]”.

Caso o Poder Público não honre os compromissos assumidos, o parceiro privado poderá executar a garantia prestada pelo FGP, que, por sua vez, cobrará o crédito da Administração Pública contratante para a recomposição de seu patrimônio e, conseqüentemente, a assunção de obrigações referentes a outros contratos de PPP.

A natureza jurídica do FGP, bem como sua viabilidade em face do regime jurídico dos bens públicos vigente no Brasil constituem o tema central do presente estudo, a ser abordado no capítulo seguinte.

Com o objetivo de atrair os financiamentos necessários aos projetos de PPP, outra novidade trazida pela Lei $\mathrm{n}^{\circ} 11.079 / 04$ foi a possibilidade de emissão de empenho em favor dos financiadores do projeto, para que os mesmos possam receber, diretamente, a contraprestação devida pelo Poder Público (artigo $5^{\circ}, \S 2^{\circ}$, II). Os financiadores também poderão receber diretamente eventuais pagamentos devidos por parte dos garantidores, bem 
como indenizações decorrentes da extinção antecipada do contrato (artigo $\left.5^{\circ}, \S 2^{\circ}, \mathrm{III}\right)$.

Em linhas gerais, estas são as principais características dos contratos de PPP. Como se pode notar, a assunção de obrigações pecuniárias por parte da Administração Pública constitui importante diferencial do novo regime, motivo pelo qual uma das principais, senão a principal preocupação para a viabilidade do novo instrumento, consiste na estruturação de mecanismos de garantia realmente eficazes.

Este foi justamente um dos temas centrais das discussões travadas no Congresso Nacional, no decurso do processo legislativo, merecendo destaque a questão do funcionamento do fundo garantidor das PPPs no nível federal, a ser tratado no próximo capítulo ${ }^{30}$.

\footnotetext{
${ }^{30}$ Conforme Parecer $N^{o}$, de 2004, apresentado pelo Senador Valdir Raupp em 18 de maio de
} 2004, na $16^{\mathrm{a}}$ reunião ordinária da Comissão de Assuntos Econômicos. 


\section{4 \\ O Fundo Garantidor das PPPs no Âmbito Federal}

\section{1}

\section{Principais Características do Fundo Garantidor de Parcerias Público-Privadas - FGP}

Conforme mencionado no capítulo anterior, a Lei $\mathrm{n}^{\mathrm{o}}$ 11.079/04 pretende implementar, no Brasil, um novo modelo de contratação administrativa, que possibilite o desenvolvimento de grandes empreendimentos — principalmente na área de infra-estrutura —, cuja realização não é economicamente viável pelo Poder Público, isoladamente, ou pela iniciativa privada, através dos instrumentos tradicionais como a concessão de serviço público.

A fim de viabilizar projetos de grande vulto, a Lei das PPPs estabeleceu um sistema de remuneração ao parceiro privado distinto dos até então praticados, composto não somente pela tarifa cobrada do usuário do serviço - no caso da concessão patrocinada - mas também pela contraprestação devida pelo parceiro público. Segundo Hely Lopes 
Meirelles" ${ }^{31}$, "esta participação financeira da Administração é a característica principal desta nova modalidade de parceria".

E segue o autor:

"Por isso, a lei procura especificar as formas de contraprestação do Poder Público, listando as garantias que podem ser oferecidas (art. $8^{\circ}$ ), admitindo até mesmo a vinculação de receitas, desde que observado o disposto no inc. IV do art. 167 da CF."

Considerando o aporte de recursos públicos nos projetos de PPP, o elevado volume de investimentos privados a serem realizados nos futuros contratos - cujos valores não poderão ser inferiores a $R \$ 20$ milhões bem como a imagem negativa da Administração Pública no que tange ao cumprimento das obrigações contraídas com terceiros, a Lei $\mathrm{n}^{\circ}$ 11.079/04 previu um amplo leque de garantias para as contraprestações assumidas pelo parceiro público, com o intuito de atrair investidores para os projetos de PPP.

Acerca da importância da estabilidade do novo modelo, vale transcrever trecho da obra de Renato Poltronieri ${ }^{32}$ sobre as Parcerias Público-Privadas:

"Diante de seu histórico e do que se pretende instituir no Brasil, deve ficar muito claro ao legislador que o relacionamento entre setor público e privado de milhões de reais ao longo de décadas exige uma estrutura estável

\footnotetext{
${ }^{31}$ MEIRELLES, Hely Lopes, Direito Administrativo Brasileiro, $30^{\mathrm{a}}$ edição, Ed. Malheiros, 2005, p. 387.

32 POLTRONIERI, Renato, Parcerias Público-Privadas e a Atuação Administrativa, Ed. Juarez de Oliveira, 2005, p. 63.
} 
e precisa, já que envolve investimentos e dividas de longo prazo que podem passar, inclusive, de uma geração para outra."

No mesmo sentido, assevera o autor José dos Santos Carvalho Filho $^{33}$ :

"A parceria público-privada evidencia clara preocupação em evitar que o concessionário, a cujo cargo ficaram os investimentos no serviço ou na obra pública, sofra prejuizos ou corra riscos diante de eventual inadimplemento do poder concedente ou até mesmo em virtude de fatos imprevisiveis. Por tal motivo, a lei consignou as garantias que podem ser contratadas relativamente às obrigações contraídas pela Administração Pública (art. $8^{\circ}$ )."

Com este propósito, de assegurar a maior segurança jurídica e financeira possível nos contratos de PPP, a Lei n ${ }^{\circ}$ 11.079/04 previu, em seu artigo $8^{\circ}$, uma série de modalidades de garantias, dentre elas as que poderão ser prestadas por fundo garantidor (inciso V). Com fulcro neste dispositivo, a mesma lei, mais adiante, autorizou a constituição de um fundo de âmbito federal com o objetivo de garantir as obrigações assumidas pela Administração Pública nos contratos de PPP. É o que dispõe o caput do artigo 16 da referida lei:

"Art. 16. Ficam a União, suas autarquias e fundações públicas autorizadas a participar, no limite global de $R \$$ 6.000.000.000,00 (seis bilhões de reais), em Fundo Garantidor de Parcerias Público

\footnotetext{
${ }^{33}$ CARVAlHO FILHO, José dos Santos, Manual de Direito Administrativo, $13^{\mathrm{a}}$ edição, Ed. Lumen Juris, 2005, p. 332.
} 
Privadas - FGP, que terá por finalidade prestar garantia de pagamento de obrigações pecuniárias assumidas pelos parceiros públicos federais em virtude das parcerias de que trata este Lei."

As garantias a serem prestadas pelo FGP, nos termos do parágrafo $1^{\circ}$ do artigo 18, poderão assumir as seguintes modalidades: fiança, sem benefício de ordem para o fiador; penhor; hipoteca; alienação fiduciária e outros contratos com efeito de garantia.

De acordo com o texto legal, o FGP terá natureza privada e patrimônio próprio separado do patrimônio dos cotistas, sendo sujeito de direitos e obrigações próprios. Em conseqüência, diz a Lei que o Fundo responderá por suas obrigações com seu próprio patrimônio, não respondendo os cotistas por quaisquer obrigações, salvo pela integralização da cotas que subscreverem (artigo $16, \S \S 1^{\circ}$ e $5^{\circ}$ ).

Quanto ao patrimônio do FGP, a Lei das PPPs estabelece que este será formado pelo aporte de bens e direitos realizado pelos cotistas, através da integralização de cotas, e pelos rendimentos decorrentes da administração do Fundo. A integralização poderá ser efetivada em “dinheiro, titulos da dívida pública, bens imóveis dominicais, bens móveis, inclusive ações de sociedade de economia mista federal excedentes ao necessário para a manutenção de seu controle pela União, dentre outros direitos com valor patrimonial" (artigo 16, $\S \S 2^{\circ} \mathrm{e} 4^{\circ}$ ).

A transferência de bens e direitos ao FGP deverá ser precedida de avaliação por empresa especializada e autorização do Presidente da República, por proposta do Ministro da Fazenda, não sendo necessária a realização de prévio certame licitatório. Note-se que quando se tratar de bem público de uso especial ou de uso comum, a transferência deverá ser 
precedida da desafetação do bem, a ser realizada de forma individualizada (artigo $16, \S \S 3^{\circ}, 6^{\circ}$ e $7^{\circ}$ ).

O primeiro ato normativo regulamentando o FGP foi editado em 06 de abril de 2005, através do Decreto $\mathrm{n}^{0}$ 5.411, que autorizou a integralização de cotas no Fundo mediante a transferência de ações de propriedade da União relativas a participações minoritárias e participações excedentes à manutenção de seu controle em sociedades de economia mista.

No Anexo I, o Decreto elenca as ações a serem transferidas ao FGP anteriormente vinculadas ao Fundo Nacional de Desestatização - FND e ao Fundo de Amortização da Dívida Pública Mobiliária Federal - FAD. A desvinculação de tais participações dos referidos fundos é autorizada no próprio corpo do ato normativo (parágrafo único do artigo $1^{\circ}$ ).

O Anexo II do Decreto, por sua vez, identifica outras ações de propriedade da União a serem transferidas ao FGP. Trata-se da participação acionário do Governo Federal nas seguintes empresas: Eletrobrás, Coelba, Celpe, Comgás, Coelce, Gerdau e Rhodia-Ster.

Observe-se ainda que, além das ações especificadas nos anexos, o artigo $2^{\circ}$ do Decreto $\mathrm{n}^{\mathrm{o}}$ 5.411/05 autoriza, de forma genérica, " $a$ integralização com outras ações da União [...] representativas de suas participações minoritárias em percentual inferior a cinco por cento do capital total da respectiva empresa e do excesso à manutenção do seu controle em sociedades de economia mista".

No que se refere à criação, administração, gestão e representação judicial e extrajudicial do FGP, a Lei das PPPs estabelece que tais atribuições competirão a instituição financeira controlada, direta ou indiretamente, pela União, a qual caberá, portanto, as deliberações acerca 
da alienação dos bens e direitos do Fundo (artigo 17). A escolha da instituição financeira, bem como o mecanismo de funcionamento do FGP dependem ainda de regulamentação específica. 


\section{2}

\section{A Instituição do FGP e a Constituição de 1988}

De acordo com o artigo $165, \S 9^{\circ}$, II, da Constituição Federal, cabe à lei complementar estabelecer "condições para a instituição $e$ funcionamento de fundos". O artigo 167, IX, por sua vez, determina que é vedada "a instituição de fundos de qualquer natureza, sem prévia autorização legislativa".

Quanto ao primeiro requisito, conforme entendimento do Supremo Tribunal Federal - manifestado no julgamento da medida liminar na Ação Direta de Inconstitucionalidade $\mathrm{n}^{\mathrm{o}} 1.726-5 / \mathrm{DF}^{34}$ (“ADIn”) —, no que tange aos fundos especiais, a exigência constitucional encontra-se plenamente satisfeita, dada a recepção da Lei n $4.320 / 64$ pela Carta Política de 1988, com status de lei complementar.

Por fundos especiais, nos termos da Lei $n^{\circ} 4.320 / 64$, entende-se aqueles constituídos do "produto de receitas especificadas que por lei se vinculam à realização de determinados objetivos ou serviços, facultada a adoção de normas peculiares de aplicação" (artigo 71).

\footnotetext{
${ }^{34}$ STF, ADIn n ${ }^{\circ}$ 1.726-5/DF (medida liminar), Relator Ministro Maurício Corrêa, decidida em 16.09.1998, D.J. 30.04.2004.
} 
Uma das principais questões discutidas na ADIn supracitada é o descumprimento do preceito contido no artigo $165, \S 9^{\circ}$, II, da Constituição Federal, quando da edição da Lei $n^{\circ}$ 9.531/97, que criou o Fundo de Garantia para Promoção da Competitividade - FGPC.

A fim de verificar a suposta violação constitucional, a Egrégia Corte confrontou o artigo $1^{\circ}$ da Lei $n^{\circ} 9.531 / 97$ com o artigo 71 da Lei $n^{\circ}$ 4.320/64, transcrito acima, que define os fundos especiais. Observe-se a redação do dispositivo da Lei no 9.531/97:

"Art.1". Fica criado o Fundo de

Garantia para promoção da Competitividade - FGPC, de natureza contábil, vinculado ao Ministério do Desenvolvimento, Indústria e Comércio Exterior e gerido pelo Banco Nacional de Desenvolvimento Econômico e Social-BNDES, com a finalidade de prover recursos para garantir o risco das operações de financiamento realizadas pelo BNDES e pela Agência Especial de Financiamento Industrial - FINAME ou por intermédio de instituições financeiras repassadoras, destinadas a: $[\ldots] "$

A partir da análise da legislação mencionada cima, o Supremo Tribunal Federal — em sede de apreciação de medida liminar — entendeu tratar-se o FGPC de fundo especial, para o qual a exigência de lei complementar prevendo as condições para sua instituição e funcionamento encontra-se satisfeita pela Lei $n^{\circ} 4.320 / 64$.

Nesse sentido, observe-se trecho do voto proferido pelo relator, Ministro Maurício Corrêa, ao analisar o requisito estabelecido no artigo 
$165, \S 9^{\circ}$, II, da Constituição Federal, bem como o enquadramento do FGPC como fundo especial:

\begin{abstract}
"É que até agora não tendo sido editada lei complementar que discipline o preceito constitucional invocado, a Lei $n^{\circ} 4.320$, de 17 de março de 1964, que instituiu normas gerais de direito financeiro para elaboração e controle dos orçamentos da União está recepcionada pela Constituição Federal, com status de lei complementar, visto que do contrário restaria de braços cruzados, e em pânico, a Administração Pública, impedida que estaria de realizar as suas atividades institucionais. [...] Com efeito, esse diploma legal, utilizando a expressão fundo especial (artigos 71 a 74), nada mais fez do que defini-lo (artigo 71), impondo as condições para sua instituição e funcionamento (artigos 72 a 74). [...] Não há dúvida que o FGPC se ajusta à definição de fundo especial, o que se pode verificar cotejando-se o artigo $1^{\circ}$ da Lei $n^{\circ} 9.531 / 97$, com o artigo 71 da Lei $n^{\circ} 4.320 / 64$, ao exigir que haja produto de receitas especificadas por lei, exista vinculação à realização de seus objetivos ou serviços; sejam previstas normas peculiares de aplicação e haja vinculação a determinado órgão da Administração."
\end{abstract}

Considerando o entendimento do Supremo Tribunal Federal manifestado acima - não sendo demais lembrar que a matéria ainda carece de decisão final - , vejamos se, no que se refere ao FGP, foi observado o requisito constante do artigo $165, \S 9^{\circ}$, II, da Constituição da República. 
Para tanto, a primeira providência que se coloca é saber se o FGP se caracteriza como fundo especial.

A esse respeito, é importante notar que, embora o Ministro Maurício Corrêa aponte, dentre os aspectos que caracterizam os fundos especiais, a necessidade de vinculação a determinado órgão da Administração, a Lei ${ }^{0}$ 4.320/64 prevê apenas que "constitui fundo especial o produto de receitas especificadas que por lei se vinculam à realização de determinados objetivos ou serviços, facultada a adoção de normas peculiares de aplicação".

Observe-se que apenas dois aspectos são impositivos para a caracterização dos fundos especiais: a constituição a partir do produto de receitas especificadas e a vinculação à realização de determinados objetivos ou serviços. As demais normas previstas na Lei no 4.320/64 sobre a matéria tratam somente do funcionamento dos referidos fundos.

Em relação ao FGP, é possível verificar, a partir da análise da Lei $\mathrm{n}^{\mathrm{o}}$ 11.079/04, que o Fundo constitui produto de receitas especificadas - quais sejam, as elencadas no artigo 16, $\S \S 2^{\circ}$ e $4^{\circ}$ - bem como que seu patrimônio se vincula à realização de determinado objetivo, qual seja, a prestação de garantia de pagamento das obrigações assumidas pelo Poder Público em contratos de PPP (artigo 16, caput).

Não há dúvidas, portanto, que o FGP apresenta as características previstas na Lei $\mathrm{n}^{\mathrm{o}} 4.320 / 64$, motivo pelo qual podemos considerá-lo como fundo especial.

Ademais, ainda que se entenda que a vinculação a determinado órgão da Administração constitui requisito para a existência de fundo especial, pode-se dizer que o FGP será vinculado a diversas entidades da 
Administração Pública direta e indireta, tendo em vista que, tal como previsto no artigo 16 da Lei das PPPs, seus cotistas poderão ser a União, suas autarquias e fundações públicas.

Sendo assim, considerando que o FGP tem natureza de fundo especial, resta satisfeita a exigência constitucional estabelecida no artigo 165 , $\S 9^{\circ}$, II, estando suas condições de instituição e funcionamento previstas na Lei no 4.320/64, recepcionada pela Carta Política de 1988 com status de lei complementar.

Nesta linha, e em conformidade com o atual posicionamento do Supremo Tribunal Federal, pedimos vênia para discordar do autor Kiyoshi Harada $^{35}$ ao sustentar, em parecer elaborado a pedido da Ordem dos Advogados do Brasil de São Paulo, que a autorização para a União participar do FGP fere o citado dispositivo constitucional:

"Ora, se a Constituição Federal
extinguiu todos os fundos até então
existentes, com exceção dos fundos
resultantes de isenções fiscais e
subordinou a criação de novos fundos
à prévia regulamentação, por lei
complementar, das condições para a
instituição efuncionamento de fundos',
como é possível ao legislador
ordinário autorizar a instituição de um
fundo específico em que a União
ingressa com a bagatela de R\$
6.000.000.000,0 (seis bilhões de
reais)?"

Como se viu, pode-se dizer que o FGP tem natureza de fundo especial, encerrando-se a discussão acerca da inexistência da lei complementar exigida pela Constituição de 1988.

\footnotetext{
${ }^{35}$ HARADA, Kiyoshi, Inconstitucionalidade do Fundo Garantidor das Parcerias Público-Privadas. Art. $8^{\circ}$ da Lei no $11.079 / 04$, Jus Navegandi, p. 9.
} 
Quanto à necessidade de prévia autorização legislativa para a instituição de fundos de qualquer natureza - prevista no artigo 167, IX, da Constituição Federal —, não há maiores discussões, tendo sido plenamente observada com a edição da Lei n ${ }^{\circ} 11.079 / 04$.

Por todo o exposto neste item, entendemos que a Lei das PPPs é constitucional no que tange à autorização para a criação do FGP prevista em seu artigo 16, caput, sendo oportuno destacar o caráter preliminar da presente análise, seja pela inexistência de regulamentação específica relacionada ao Fundo, seja pela ausência de decisão final do STF nos autos da ADIn $n^{\circ} 1.726-5 / D F$, comentada acima. 


\section{3}

\section{O Patrimônio de Constituição do FGP e sua Natureza Privada}

Outro ponto da Lei das PPPs que merece a atenção da doutrina é o que se refere ao patrimônio de constituição do FGP, bem como a sua natureza privada. Conforme citado nos capítulos anteriores, este constitui o tema central do presente estudo, cabendo destacar que são poucos os autores que já se posicionaram sobre a matéria. Tendo em vista que ainda não foi editada a respectiva regulamentação pelo Executivo Federal, ressaltamos desde já o caráter preliminar da análise exposta a seguir.

Feitas estas considerações, vejamos o disposto no artigo 16, caput, e parágrafos $1^{\circ}, 2^{\circ}$ e $4^{\circ}$ da Lei $n^{\circ} 11.079 / 04$, que tratam do fundo garantidor das PPPs:

"Art. 16. Ficam a União, suas autarquias e fundações públicas autorizadas a participar, no limite global de $R \$$ 6.000.000.000,00 (seis bilhões de reais), em Fundo Garantidor de Parcerias PúblicoPrivadas - FGP, que terá por finalidade prestar garantia de pagamento de obrigações pecuniárias assumidas pelos parceiros públicos federais em virtude das parcerias de que trata este Lei. 
$\S 1^{\circ}$. O FGP terá natureza privada e patrimônio próprio separado do patrimônio dos cotistas, e será sujeito a direitos e obrigações próprios.

$\S 2^{\circ}$. O patrimônio do Fundo será formado pelo aporte de bens e direitos realizado pelos cotistas, por meio da integralização de cotas e pelos rendimentos obtidos com sua administração. [...]

$\S 4^{\circ}$. A integralização das cotas poderá ser realizada em dinheiro, títulos da dívida pública, bens imóveis dominicais, bens móveis, inclusive ações de sociedade de economia mista federal excedentes ao necessário para manutenção de seu controle pela União, ou outros direitos com valor patrimonial. [...]"

(grifos acrescentados)

Em conseqüência da natureza privada atribuída ao FGP, estabeleceu ainda a Lei $\mathrm{n}^{\circ}$ 11.079/04 que "em caso de inadimplemento [por parte da Administração Pública], os bens e direitos do Fundo poderão ser objeto de constrição judicial [...] para satisfazer as obrigações garantidas" (artigo $\left.18, \S 7^{\circ}\right)$.

Como se passará a demonstrar, tendo em vista que o FGP será constituído de bens da União, suas autarquias e fundações públicas portanto de bens públicos —, o rótulo legal a ele conferido não será suficiente para afastar a incidência do regime de direito público sobre o seu patrimônio.

Quanto à conceituação dos bens públicos, é importante observar a definição legal, prevista no Código Civil, bem como as definições doutrinárias trazidas pelos principais administrativistas. 
De acordo com o artigo 98 do Código Civil, "são públicos os bens do domínio nacional pertencentes às pessoas jurídicas de direito público interno [...]”. No artigo 99, o Código especifica as categorias de bens públicos existentes, como se observa da transcrição abaixo:

“Art. 99. São bens públicos:

I - os de uso comum do povo, tais como rios, mares, estradas, ruas e praças;

II - os de uso especial, tais como edificios ou terrenos destinados a serviço ou estabelecimento da administração federal, estadual, territorial ou municipal, inclusive os de suas autarquias;

III - os dominicais, que constituem o patrimônio das pessoas jurídicas de direito público, como objeto de direito pessoal, ou real, de cada uma dessas entidades.

Parágrafo único. Não dispondo a lei em contrário, consideram-se dominicais os bens pertencentes às pessoas jurídicas de direito público a que se tenha dado estrutura de direito privado".

Quanto à abordagem da doutrina sobre o tema, ensina Hely Lopes Meirelles $^{36}$ que integram o universo dos bens públicos "todas as coisas, corpóreas ou incorpóreas, imóveis, móveis ou semoventes, créditos, direitos e ações, que pertençam, a qualquer título, às entidades estatais, autárquicas, fundacionais e empresas governamentais". Segundo o autor, o conceito adotado pelo Código Civil "não deixa dúvidas quanto ao fato de que também são bens públicos os pertencentes às autarquias e fundações públicas".

\footnotetext{
${ }^{36}$ MEIRELLES, Hely Lopes, Direito Administrativo Brasileiro, $30^{\mathrm{a}}$ edição, Ed. Malheiros, 2005, p. 501.
} 
Para Diógenes Gasparini ${ }^{37}$, "bens públicos são todas as coisas materiais e imateriais pertencentes ou não às pessoas jurídicas de Direito Público e as pertencentes a terceiros quando vinculadas à prestação de serviço público". E segue o autor:

"São pessoas jurídicas de Direito Público a União, cada um dos Estados-Membros, o Distrito Federal, cada um dos Municipios, as autarquias $e$ as fundações públicas. Assim, os bens pertencentes a essas pessoas públicas são bens públicos. Também são bens públicos, consoante essa definição, os de propriedade de terceiros quando vinculados à prestação de serviço público. [...] Desse modo, não são, salvo em sentido amplíssimo, bens públicos os que integram o patrimônio das empresas governamentais (sociedades de economia mista, empresa pública, subsidiárias) exploradoras de atividade econômica, porque pessoas privadas $\left(C F\right.$, art. $\left.173, \S 1^{\circ}, I I\right)$. Ademais, ditos bens não estão vinculados à execução de qualquer serviço público. O mesmo ocorre com a fundação privada cujo objeto não seja a prestação de serviço público."

Definição semelhante é apresentada por Celso Antônio Bandeira de $\mathrm{Mello}^{38}$, para quem a análise da vinculação do bem a determinado serviço público - além da natureza da entidade detentora do mesmo — também é fundamental para a caracterização dos bens públicos:

\footnotetext{
${ }^{37}$ GASPARINI, Diógenes, Direito Administrativo, 5 a edição, Ed. Saraiva, 2002, p. 646-647.

38 BANDEIRA DE MELLO, Celso Antônio, Curso de Direito Administrativo, $17^{\mathrm{a}}$ edição, Ed.Malheiros, 2004, p. 803.
} 
"Bens públicos são todos os bens que pertencem às pessoas jurídicas de Direito Público, isto é, União, Estados, Distrito Federal, Municípios, respectivas autarquias e fundações de Direito Público (estas últimas, aliás, não passam de autarquias designadas pela base estrutural que possuem), bem como os que, embora não pertencentes a tais pessoas, esteja, afetados à prestação de um serviço público."

Note-se que não há divergência na doutrina quanto ao fato de que os bens das autarquias e fundações públicas constituem bens públicos. Nesse sentido, vale transcrever os comentários de Jorge Ulisses Jacoby Fernandes ${ }^{39}$ no que se refere à natureza dos bens das autarquias:

"É jurisprudência assentada que, quando pessoas jurídicas de direito público, como a União, Estados, Municipios e Distrito Federal, criam autarquias $e$ lhes transferem a propriedade de bens, esses conservam a característica de público."

Outra não é a orientação da jurisprudência, da qual serve de exemplo a decisão proferida pelo Superior Tribunal de Justiça transcrita a seguir:

"Conflito de Competência. Crime praticado contra entidade de ensino superior. Art. 109, I, da CF/88.

- Compete à Justiça Federal o julgamento de crime praticado em detrimento de bens de universidade instituída e mantida pela União como fundação de direito público, posto que equiparada às autarquias ou mesmo empresas públicas federais.

\footnotetext{
39 JACOBY FENANDES, Jorge Ulisses, Vade-Mécum de Licitações e Contratos, Ed. Fórum, 2004, p. 221.
} 
- Aplicação do art.109, I, da CF/1988.

- Competência, 'in causu', do juízo federal, suscitado. ",40

(grifos acrescentados)

Em relação à importância da destinação do bem para a sua caracterização como bem público, vale transcrever a ementa da decisão proferida pelo Tribunal Regional Federal da Quarta Região nos autos do Agravo de Instrumento $\mathrm{n}^{\circ} 9604191020$ :

"Tributário. Execução proposta contra fundação municipal. Rito.

As fundações voltadas a uma finalidade pública, ainda que constituídas com personalidade de Direito Privado, são espécies do gênero autarquia, com os mesmos privilégios e garantias conferidos a esta, consoante entendimento consolidado pelo STF. Como corolário, as execuções contra elas intentadas não se submetem ao rito previsto na Lei 8630/82, mas àquele contido no art. 730 do CPC/73.

(grifos acrescentados)

Resta claro, portanto, que os bens que constituirão o FGP, uma vez pertencentes à União, suas autarquias e fundações públicas, integram o rol dos bens públicos.

Em conseqüência, deverão ser observados, na gestão de tais bens, os preceitos decorrentes do Princípio da Indisponibilidade dos Bens Públicos, quais sejam, a inalienabilidade, a imprescritibilidade, a impenhorabilidade e a impossibilidade de oneração. Como se verá adiante, tais atributos não são absolutos, comportando as exceções devidamente previstas em lei.

\footnotetext{
${ }^{40}$ STJ, $3^{\text {a }}$ Seção, CC no 7799/MG, Relator Min. Cid Flaquer Scartezzini, DJ 19.05.1997.

${ }^{41}$ TRF, $4^{\mathrm{a}}$ Região, $2^{\mathrm{a}}$ Turma, AG nº 9604191020/RS, Relatora Juíza Tânia Terezinha Cardoso Escobar, DJ 16.07.1997.
} 
Passemos, pois, à análise de cada uma destas características.

\section{Inalienabilidade}

Por inalienabilidade, entende-se a vedação da transferência de determinado bem ao patrimônio de terceiro.

Em se tratando de bens públicos, a inalienabilidade deve ser entendida como alienabilidade nos termos da lei, sendo certo que sempre serão inalienáveis os bens afetados à consecução de determinada finalidade pública, como é o caso dos bens públicos de uso comum do povo e de uso especial.

No entanto, uma vez desafetados por lei os bens citados acima, passarão os mesmos a integrar o rol dos bens públicos dominicais, podendo ser objeto de alienação. É o que dispõe o artigo 100 do Código Civil:

"Art. 100. Os bens públicos de uso comum do povo e os de uso especial são inalienáveis, enquanto conservarem a sua qualificação, na forma que a lei determinar."

Os bens públicos dominicais, por não serem vinculados a atividade de interesse público específica, podem ser alienados, desde que observadas as exigências estabelecidas em lei, merecendo destaque a Lei $n^{\circ}$ 8.666/93 - Lei de Licitações, que prevê as diretrizes para as alienações efetivadas em todas as esferas da Administração Pública. Nesse sentido, observe-se o disposto no artigo 101 do Código Civil: 
“Art. 101. Os bens públicos dominicais podem ser alienados, observadas as exigências da lei."

Sobre o tema, vale citar os ensinamentos de Celso Antônio Bandeira de Mello ${ }^{42}$ :

"Inalienabilidade ou alienabilidade nos termos da lei, característica esta expressamente referida no art. 100 do Código Civil. Os de uso comum ou especial não são alienáveis enquanto conservarem tal qualificação isto é, enquanto estiverem afetados a tais destinos. Só podem sê-lo (sempre nos termos da lei) ao serem desafetados, passando à categoria dos dominiais. $O$ fato de um bem estar na categoria de dominical não significa, entretanto, que só por isto seja alienável ao alvedrio da Administração, pois o Código Civil, no artigo 101, dispõe que: 'Os bens públicos dominicais podem ser alienados, observadas as exigências da lei'."

Não é demais lembrar que, ainda que se entenda que o Código Civil não constitui diploma apto a legislar sobre matéria administrativa de competência estadual ou municipal, a subordinação da gestão e alienação de bens públicos à lei decorre do Princípio da Legalidade, que, para o administrador público, significa a delimitação de toda a sua atividade aos estritos ditames legais.

Portanto, a instituição financeira que administrará o FGP deverá observar as exigências legais para a alienação dos bens que formarão o

\footnotetext{
${ }^{42}$ BANDEIRA DE MELLO, Celso Antônio, Curso de Direito Administrativo, $17^{\mathrm{a}}$ edição, Ed. Malheiros, 2004, p. 805-806.
} 
Fundo, uma vez que não se trata de mera gestão de bens privados, mas sim da administração de patrimônio público.

\section{Imprescritibilidade}

Outra característica do regime dos bens públicos é a imprescritibilidade. Está prevista nos artigos $183, \S 3^{\circ}$, e 191, parágrafo único, da Constituição Federal, segundo os quais "os imóveis públicos não serão adquiridos por usucapião"43. Trata-se de atributo decorrente da inalienabilidade, fazendo parte da tradição normativa brasileira desde o Brasil-Colônia.

Nesse sentido, Hely Lopes Meirelles ${ }^{44}$ :

"[...] se os bens públicos são
originariamente inalienáveis, segue-se
que ninguém os pode adquirir
enquanto guardarem essa condição.
Dai não ser possivel a invocação de
usucapião sobre eles. É principio
jurídico, de aceitação universal, que
não há direito contra Direito, ou, por
outras palavras, não se adquire direito
em desconformidade com o Direito"

Como se pode verificar, a imprescritibilidade, que cuida de proteger a propriedade dos bens públicos contra a aquisição por usucapião, também deverá ser observada no que se refere aos bens que integrarão o FGP.

\footnotetext{
${ }^{43}$ Há previsões semelhantes no artigo 102 do Código Civil, no artigo 200 do Decreto-Lei $n^{\circ}$ 9.760/46 e na Súmula n ${ }^{\circ} 340$ do Supremo Tribunal Federal.

${ }^{44}$ MEIRELLES, Hely Lopes, Direito Administrativo Brasileiro, $30^{\mathrm{a}}$ edição, Ed. Malheiros, 2005, p. 524 .
} 


\title{
Impenhorabilidade
}

Outro traço distintivo do regime jurídico aplicável aos bens públicos é a impenhorabilidade. Como ensina a doutrina, esta decorre da previsão constitucional constante do artigo 100, caput, transcrita abaixo:

\begin{abstract}
"Art. 100. À exceção dos créditos de natureza alimentícia, os pagamentos devidos pela Fazenda Federal, estadual ou Municipal, em virtude de sentença judiciária, far-se-ão exclusivamente na ordem cronológica de apresentação dos precatórios e à conta dos créditos respectivos, proibida a designação de casos ou de pessoas nas dotações orçamentárias e nos créditos adicionais abertos para este fim."
\end{abstract}

Leciona Hely Lopes Meirelles ${ }^{45}$ que "a impenhorabilidade dos bens públicos decorre de preceito constitucional que dispõe sobre a forma pela qual serão executadas as sentenças judiciárias contra a Fazenda Pública, sem permitir a penhora de seus bens".

No mesmo sentido, observe-se as lições de Diógenes Gasparini ${ }^{46}$, que se refere ainda à previsão constante do Código de Processo Civil:

"A impenhorabilidade resguarda os bens públicos, não permitindo que sobre eles recaia penhora. A esse respeito prescreve o Código de Processo Civil que os bens inalienáveis são absolutamente impenhoráveis (art. 649, I). Por essa razão é que se tem um processo de execução contra a Administração

\footnotetext{
${ }^{45}$ MEIRELLES, Hely Lopes, Direito Administrativo Brasileiro, $30^{\mathrm{a}}$ edição, Ed. Malheiros, 2005, p. 524.

${ }^{46}$ GASPARINI, Diógenes, Direito Administrativo, $5^{\text {a }}$ edição, Ed. Saraiva, 2002, p. 655.
} 
Pública (pessoa jurídica de Direito Público) diferente do processo para a execução contra as pessoas de Direito privado. Substancialmente, essa diferença reside na inexistência da penhora. O processo, no caso, observa o que estabelece o art. 100 da Constituição da República, de onde decorre tal diferenciação."

Como destacado pelo autor, o Código de Processo Civil dispõe, em seu artigo 649, I, que "são absolutamente impenhoráveis [...] os bens inalienáveis [...]”. Com efeito, conforme visto acima, uma das características dos bens públicos é justamente a sua inalienabilidade.

Por óbvio, a impenhorabilidade veda que os bens públicos sejam objeto de penhora, instituto que permite a constrição judicial de bens para o cumprimento de obrigações requerido em juízo.

E note que o ordenamento jurídico pátrio não faz distinção entre as categorias de bens públicos para fins de proibição de penhora, sustentando alguns autores que esta não poderá incidir sobre quaisquer bens públicos, sejam estes bens de uso comum do povo, de uso especial ou dominicais. $\mathrm{Na}$ esteira deste entendimento, citamos Maria Sylvia Zanella Di Pietro ${ }^{47}$ :

"Em primeiro lugar, o artigo 100 da Constituição, que estabelece processo especial de execução contra a Fazenda Pública, excluindo, implicitamente, a penhora sobre qualquer tipo de bem público pertencente à União, Estados Municípios e respectivas autarquias."

Quanto à equiparação das fundações públicas às autarquias — ambas autorizadas a participar do FGP — e à conseqüente impenhorabilidade dos

\footnotetext{
${ }^{47}$ DI PIETRO, Maria Sylvia Zanella, Direito Administrativo, 14 a edição, Ed. Atlas, 2002, p. 549.
} 
bens das primeiras, existe vasta jurisprudência, cabendo ressaltar que todas as decisões transcritas a seguir foram unânimes:

"Resp. Administrativo. Processual Civil. Fundação de direito público. Bens. Impenhorabilidade. Preclusão.

- Os bens de fundação de direito público são impenhoráveis. Em ocorrendo a preclusão quanto ao debate dessa matéria, não pode ser reaberta em recurso especial. Caso contrário, restará afetada a finalidade do processo que é definir a situação jurídica de direito narrado, na causa de pedir, cuja postulação consta do pedido. Eventual combate jurídico deverá travar-se em ação própria." 48

(grifos acrescentados)

"Processual Civil. Execução Fiscal.

Fundação Pública. Procedimento.

Penhora.

1. Bens de propriedade de fundação pública municipal são impenhoráveis, não se lhe aplicando o procedimento previsto na Lei 6830/80, mas sim o constante do art. 730 do CPC.

2. Penhora e arrematação que se consideram nulas.

3. Apelação provida. "49

(grifos acrescentados)

"Processo Civil. Embargos à

Execução. Apelo. Razões da Impugnação. Fundação Pública. Penhora.

1. Não satisfaz a exigência legal a simples referencia, nas razões de

\footnotetext{
${ }^{48}$ STJ, 6a Turma, Resp n ${ }^{\circ}$ 147341/SP, Relator Min. Luiz Vicente Cernicchiaro, DJ 15.12.1997.

49 TRF, $1^{\mathrm{a}}$ Região, $4^{\mathrm{a}}$ Turma, AC $\mathrm{n}^{\mathrm{o}}$ 8901249324/MG, Relator Juiz Eustáquio Silveira, DJ 07.12.1992.
} 
recurso, às alegações da impugnação. Recurso não conhecido.

2. São impenhoráveis os bens das fundações públicas, a quem se aplica o tratamento dispensado às autarquias. " 50

(grifos acrescentados)

"Processo Civil. Executivo Fiscal. Administrativo. Fundação Pública.

1. A fundação pública tem a mesma natureza jurídica das autarquias. Nesta condição submete-se às regras do art. 730 do CPC, o que torna seus bens impenhoráveis.

2. Apelação improvida". ${ }^{51}$

(grifos acrescentados)

Não obstante parte da doutrina defender a impenhorabilidade de quaisquer bens públicos, como se verá no item seguinte, há casos em que será possível a penhora. Por esse motivo, trataremos da previsão constante do parágrafo $7^{\circ}$ do artigo 18 da Lei das PPPs, que permite a constrição judicial dos bens e direitos integrantes do FGP, no item abaixo.

\section{Não-Oneração}

A oneração de determinado bem está relacionada à instituição de garantias sobre o mesmo, tais como o penhor, a anticrese e a hipoteca. De acordo com o artigo 1.225 do Código Civil, as referidas modalidades de garantia constituem direito real, pelo que acompanham o bem em todas as suas mutações até a extinção da obrigação garantida.

\footnotetext{
${ }^{50}$ TRF, $4^{\text {a }}$ Região, $1^{\text {a }}$ Turma, AC n ${ }^{\text {o }}$ 9604188720/RS, Relator Juiz Vladmir Freitas, DJ 25.09.1996.

${ }^{51}$ TRF, $5^{\text {a }}$ Região, $2^{\mathrm{a}}$ Turma, AC n ${ }^{\mathrm{o}}$ 14578, Relator Juiz Araken Mariz, DJ 20.11.1992.
} 
Por esse motivo, prevê o artigo 1.419 do mesmo diploma que "nas dividas garantidas por penhor, anticrese ou hipoteca, o bem dado em garantia fica sujeito, por vínculo real, ao cumprimento da obrigação".

O artigo 1.420, por sua vez, determina que "só aquele que pode alienar poderá empenhar, hipotecar ou dar em anticrese; só os bens que se podem alienar poderão ser dados em penhor, anticrese ou hipoteca."

Em razão da regra prescrita no citado artigo 1.420, ficam, desde já, impossibilitados de serem gravados com penhor, hipoteca ou anticrese os bens públicos de uso comum do povo e de uso especial. Isso porque, conforme demonstrado acima, tais bens são inalienáveis e, logo, absolutamente impenhoráveis.

Já em relação aos bens públicos dominicais, verifica-se duas posições doutrinárias distintas.

A primeira corrente sustenta a impossibilidade de oneração dos bens dominicais. É que, segundo esta posição, embora tais bens sejam alienáveis nos termos da lei, a Constituição da República determina sua impenhorabilidade em execução judicial, o que seria incompatível com qualquer forma de garantia. A possibilidade de execução direta do bem garantido seria pressuposto lógico para a instituição da garantia.

Corroborando tal entendimento, merece destaque Hely Lopes Meirelles ${ }^{52}$ :

"Desde que a Constituição da República retirou a possibilidade de penhora de bens da Fazenda Pública

\footnotetext{
${ }^{52}$ MEIRELLES, Hely Lopes, Direito Administrativo Brasileiro, $30^{\mathrm{a}}$ edição, Ed. Malheiros, 2005, p. 525-526.
} 
federal, estadual e municipal, retirou também, a possibilidade de oneração de tais bens uma vez que a execução de toda garantia real principia pela penhora, na ação executiva correspondente, para a subseqüente satisfação da divida, mediante praceamento ou adjudicação do bem dado em garantia. Uma garantia real que não contasse com a execução direta da coisa onerada deixaria de satisfazer seus fins, desgarantindo o direito do credor. Não seria, de modo algum, garantia real."

E note que, para o referido autor, a impenhorabilidade prescrita pelo texto constitucional abrange todos os bens que constituem o patrimônio da Fazenda Pública:

"A nosso ver, a proibição
constitucional abrange todo e
qualquer bem da Fazenda Pública,
móveis, imóveis, rendas e direitos
creditórios, isentando-os de penhora.
Não importa, por igual, o fim a que se
destine a garantia real. Desde que os
bens públicos são insuscetíveis de
penhora, e sendo a penhora
consectário lógico da execução para a
satisfação do crédito objeto de
garantia real, ressalta a
impossibilidade de se constituir penhor
ou hipoteca sobre os mesmos."

Filiando-se a mesma corrente, ressalte-se o entendimento manifestado por Celso Antônio Bandeira de Mello $^{53}$ ao tratar da impenhorabilidade dos bens públicos:

53 BANDEIRA DE MELLO, Celso Antônio, Curso de Direito Administrativo, $17^{\mathrm{a}}$ edição, Ed.Malheiros, 2004, p. 806. 
"Impenhorabilidade - é uma conseqüencia do disposto no art. 100 da Constituição. Com efeito, de acordo com ele, há uma forma específica para satisfação de créditos contra o Poder Público inadimplente. Os bens públicos não podem ser praceados para que o credor neles se sacie. Assim, bem se vê que não podem também ser gravados com direitos reais de garantia, pois seria inconseqüente qualquer oneração com tal fim."

(grifos acrescentados)

No mesmo sentido, posiciona-se Maria Sylvia Zanella Di Pietro ${ }^{54}$ ao comentar a possibilidade de oneração de bens públicos sustentada por alguns autores:

"Diante, porém de direito positivo brasileiro, essa tese não é defensável, pois o processo de execução contra a Fazenda Pública obedece a normas próprias estabelecidas no artigo 100 da Constituição Federal (repetidas nos arts. 730 e 731 do CPC) e que excluem qualquer possibilidade de penhora de bem público, seja qual for a sua modalidade. Não poderia a Fazenda Pública, nem mesmo com autorização legislativa, abrir mão da impenhorabilidade com que a própria Constituição quis proteger os bens públicos de qualquer natureza."

\footnotetext{
${ }^{54}$ DI PIETRO, Maria Sylvia Zanella, Direito Administrativo, 14 edição, Ed.Atlas, 2002, p. 550.
} 
Em sentido contrário, sustenta a segunda corrente doutrinária que podem ser instituídas garantias reais sobre bens públicos dominicais, desde que por motivo de interesse público e com expressa autorização legal.

O fundamento é que se o Estado tem autonomia para legislar sobre a administração e alienação de seus bens, também o tem para legislar sobre sua oneração. Como lembra Diógenes Gasparini ${ }^{55}$, vale aqui ressaltar princípio geral de direito, segundo o qual 'quem pode o mais pode o menos'.

Assim, poderia a entidade estatal abrir mão do benefício da impenhorabilidade conferido pelo artigo 100 da Constituição da República, submetendo-se à execução comum, a fim de cumprir obrigação garantida com a devida autorização legal.

Observe-se as lições de Diógenes Gasparini ${ }^{56}$ :

"O regime de execução contra a Fazenda Pública é instituído, como também o é o princípio da indisponibilidade dos bens públicos, em benefício do Estado, e este, segundo o interesse público, pode abrir mão desse privilégio e destinar, previamente, certos bens para garantir uma dada operação. A Constituição Federal, no art. 167, IV, expressamente, prevê a vinculação de receita de impostos para garantir operações de crédito por antecipação de receita. De sorte que é legítima a garantia hipotecária incidente sobre bens públicos, bem como as conseqüências decorrentes, se tal oneração for permitida em lei."

\footnotetext{
${ }^{55}$ GASPARINI, Diógenes, Direito Administrativo, $5^{\text {a }}$ edição, Ed. Saraiva, 2002, p. 655.

${ }^{56}$ GASPARINI, Diógenes, Direito Administrativo, $5^{\text {a }}$ edição, Ed. Saraiva, 2002, p. 656.
} 
(grifos acrescentados)

Compartilhando da mesma posição, assevera Seabra Fagundes ${ }^{57}$ que há casos em que é possível conceber a execução forçada contra a Fazenda Pública, o que, hoje, afastaria a incidência do disposto no artigo 100 da Constituição vigente. Veja abaixo os comentários do publicista ao comentar tais exceções:

"Mas isso não exclui alguns casos excepcionais, em que se concebe como possivel, e mesmo necessária, a execução forçada contra a Administração Pública. Desde que tais exceções, impostas pela natureza especial de certas relações jurídicas, seja estritamente admitidas $e$ reguladas pela legislação, satisfaz-se o interesse individual sem prejudicar a vida econômica do Estado."

E segue o autor:

"Uma vez que o Estado aquiesce em firmar penhor ou hipoteca, em beneficio de credor seu abre mão, ao fazê-lo, da inalienabilidade reconhecida aos seus bens. É de notar, porém que essa renúncia à inalienabilidade peculiar dos bens públicos nem sempre é possível. Só os bens dominicais, que são facultativamente alienáveis, podem ser gravados de ônus real".

Como se pode notar, a constituição de garantia sobre um bem público está relacionada à renúncia da entidade estatal quanto à sua inalienabilidade. Isso porque, a partir do momento em que o bem é gravado

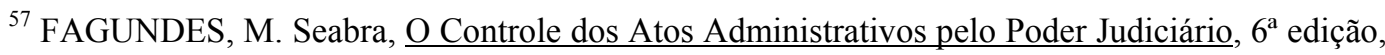
Ed. Saraiva, 1984, p. 166-168.
} 
com um ônus real, torna-se passível de execução direta, o que somente pode ocorrer em se tratando de bens públicos dominicais e mediante expressa autorização legal.

O Superior Tribunal de Justiça ${ }^{58}$, ao apreciar a legalidade de cláusula contratual na qual o Governo do Estado da Bahia concedeu garantia a particular através de vinculação de receita tributária, não obstante tenha considerado ilegal a transferência automática de tais receitas, reconheceu a possibilidade da concessão de garantia pelo Estado, uma vez que o mesmo encontrava-se legalmente autorizado.

Nesse sentido, observe-se trecho do voto do Relator Ministro Demócrito Reinaldo ${ }^{59}$ :

"In casu, se o débito realmente existe,
se as obras foram realizadas e
entregues ao estado, passando a
integrar o seu patrimônio e à
utilização do público, o contrato de
Confissão de Débito, além de ser legal,
constitui uma garantia para a empresa
recorrida e obrigação ao Estado, não
podendo ser desfeito unilateralmente
pela Administração, sponte sua, e,
ainda assim, sem observância do
devido processo legal [...]."

Com efeito, entendemos que a possibilidade da Administração instituir direitos reais de garantia sobre bens públicos dominicais faz parte do seu poder de gestão. E, como se sabe, o poder de gestão sobre os bens integrantes do patrimônio de determinada entidade estatal constitui uma das prerrogativas de sua autonomia, sem o que restaria impossibilitada a consecução das finalidades públicas a ela atribuídas.

\footnotetext{
${ }^{58}$ Recurso em Mandado de Segurança n ${ }^{\circ}$ 9.830/BA, DJ 13.12.1999.

${ }^{59}$ Note que, no curso do processo, a relatoria foi assumida pelo Ministro Humberto Gomes de Barros, em razão da aposentadoria do Ministro Demócrito Reinaldo.
} 
De outra sorte, conforme demonstrado acima, a inalienabilidade característica do regime dos bens públicos deve ser entendida como alienabilidade condicionada aos termos da lei, motivo pelo qual é correto afirmar que, em dadas circunstancias, os bens públicos são alienáveis.

Se o artigo 1.420 do Código Civil permite a instituição de garantias sobre bens alienáveis, e determinados bens públicos gozam de tal atributo, verifica-se que podem ser os mesmos dados em penhor, hipoteca ou anticrese.

Quanto aos bens que integrarão o FGP - pertencentes à União, suas autarquias e fundações públicas -, depreende-se da Lei das PPPs que estes somente poderão ser dominicais. É que, de acordo com o parágrafo $7^{\circ}$ do artigo 16, "o aporte de bens de uso especial ou de uso comum no FGP será condicionado a sua desafetação de forma individualizada". Não é demais lembrar que quando da desafetação, tais bens passarão a integrar a categoria de bens públicos dominicais, passíveis, portanto, de alienação, nos termos da lei.

Em síntese, entendemos que os bens que integrarão o FGP podem ser onerados com o intuito de garantir obrigações assumidas pela Administração Pública em contratos de PPP. No entanto, tal assertiva não decorre da 'natureza privada' atribuída pela Lei no 11.079/04, mas sim da permissão que confere o próprio regime dos bens públicos de que a oneração e a conseqüente penhora possam estar autorizadas em lei.

No caso do FGP, tanto a oneração quanto a possibilidade de constrição judicial de seus bens estão expressamente autorizadas pela Lei $\mathrm{n}^{\circ}$ 11.079/04, nos artigos 16 e 18. 
Portanto, entendemos que mero rótulo legal não é capaz de derrogar a natureza pública do FGP, ainda mais considerando que, de acordo com o parágrafo único do artigo 70 da Constituição da República, "prestará contas qualquer pessoa física ou jurídica, pública ou privada, que utilize, arrecade, guarde, gerencie ou administre dinheiros, bens e valores públicos ou pelos quais a União responda, ou que, em nome desta, assuma obrigações de natureza pecuniária”.

Embora os fundos não sejam dotados de personalidade jurídica, é notório que o que quis a Carta de 1988 foi proteger o patrimônio público, motivo pelo qual estabeleceu mecanismos de controle aptos a garantir a sua adequada destinação. Ademais, sendo os cotistas que formarão o FGP pessoas jurídicas de direito público e seu administrador instituição financeira controlada, direta ou indiretamente, pela União (artigos 16, caput, e 17), não há que se falar em natureza privada.

Ainda sobre o controle dos bens públicos, note que este será exercido pelo Congresso Nacional, com o auxílio do Tribunal de Contas da União, nos termos do artigo 71, II, da Constituição, in verbis:

"Art. 71. O controle externo, a cargo do Congresso Nacional, será exercido com o auxílio do Tribunal de Contas da União, ao qual compete: [...]

II - julgar as contas dos administradores $e$ demais responsáveis por dinheiros, bens $e$ valores públicos da administração direta $e$ indireta, incluídas as fundações e sociedades instituídas e mantidas pelo poder público federal, $e$ as contas daqueles que derem causa a perda, extravio ou outra irregularidade de que resulte prejuízo ao erário público; $[. .$.

(grifos acrescentados) 
No mesmo sentido, a Lei $n^{\circ} 4.320 / 64$, aplicável aos fundos especiais, estabelece que a lei que os instituir "poderá determinar normas peculiares de controle, prestação e tomada de contas, sem de qualquer modo, elidir a competência específica do Tribunal de Contas ou órgão equivalente" (artigo 74).

Por todo o exposto neste capítulo, temos como inconstitucional o parágrafo primeiro do artigo 16 da Lei $\mathrm{n}^{\circ} 11.079 / 04$, na parte em que atribui natureza privada ao FGP, por afrontar as citadas regras de fiscalização do patrimônio público previstas na Constituição.

Além disso, pretende o referido dispositivo derrogar o regime de direito público próprio dos bens da União, suas autarquias e fundações públicas, o que não é permitido pelo ordenamento jurídico vigente. 


\section{Conclusão}

Por todo o exposto, consideramos promissora a iniciativa do Poder Executivo Federal em instituir as Parcerias Público-Privadas no Brasil, assim como o esforço do Congresso Nacional em aprovar o projeto de lei que culminou com a publicação da Lei no 11.079/04.

Com efeito, o Estado brasileiro não se revelou capaz de prestar eficientemente os serviços públicos, motivo pelo qual apoiamos a tendência de se delegar tais atividades à iniciativa privada, seja através das concessões ou permissões de serviços públicos, seja através das PPPs ou outro instrumento criado com a finalidade de diminuir as atribuições do Estado.

Quanto à implementação das PPPs, já se verifica algumas atitudes do Governo Federal com o intuito de dar aplicabilidade à Lei ${ }^{\circ} 11.079 / 04$, cabendo ressaltar que já foi disponibilizada, com base no Plano Plurianual relativo ao período de 2004 a 2007, a 'I Carteira de Projetos de PPP ${ }^{, 60}$.

Os projetos contidos no referido documento são destinados ao incremento dos setores rodoviário, ferroviário, portuário e de irrigação, merecendo destaque, dentre as obras mais vultuosas, (i) a duplicação do

\footnotetext{
${ }^{60}$ Acessível no endereço eletrônico www.apeop.org.br/diversos/download/CarteiraPPP.pdf.
} 
trecho rodoviário na BR 101, Natal - divisa Alagoas/Sergipe; (ii) duplicação do trecho rodoviário na BR 381, Belo Horizonte - São Paulo; (iii) construção do Rodoanel Metropolitano de São Paulo - Trecho Sul; (iv) projeto de irrigação em Jaiba, norte de Minas Gerais; e (v) duplicação do trecho rodoviário na BR-116, conhecido como Regis Bittencourt.

No nível estadual, Minas Gerais, Santa Catarina, São Paulo e Goiás foram os pioneiros na elaboração das leis que regem as $\operatorname{PPPs}^{61}$, sendo que os estados do Rio Grande do Sul e do Rio de Janeiro já deram início ao processo legislativo para a implementação de suas parcerias ${ }^{62}$.

Como se pode notar, há um esforço político no sentido de desenvolver setores estruturais carentes de investimentos através da celebração de contratos de PPP. No entanto, conforme destacado acima, a implementação do novo modelo de contratação pública poderá esbarrar em uma série de restrições impostas pelo ordenamento jurídico pátrio, principalmente no que se refere à viabilidade $\mathrm{e}$ à própria constitucionalidade do Fundo Garantidor das parcerias, considerado como um dos principais mecanismos aptos a proporcionar a segurança jurídica necessária para atrair o interesse do setor privado nos projetos de PPP.

Nesse sentido, poderá ser questionada a natureza privada atribuída ao FGP pela Lei $\mathrm{n}^{0} 11.079 / 04$, o que poderá enfraquecer, dependendo da orientação adotada, a espinha dorsal do novo instituto, qual seja, o investimento público nos projetos com a assunção de obrigações pecuniárias por parte da Administração em face do parceiro privado, a fim de tornar economicamente viável a execução do empreendimento.

\footnotetext{
${ }^{61}$ Leis Estaduais ${ }^{\circ} \mathrm{s} 14.868$, de 16 de dezembro de 2003; 12.930, de 04 de fevereiro de 2004; 11.688, de 19 de maio de 2004; e 14.910, de 11 de agosto de 2004, respectivamente.

${ }^{62}$ Projetos de Lei Estadual nos 27 , de 17 de fevereiro de 2004, e 2087, de 28 de outubro de 2004, respectivamente.
} 
Além da questão da natureza privada do FGP, a eficácia do Fundo dependerá da concepção do regime dos bens públicos adotada, o que, conforme abordado, não constitui matéria pacífica na doutrina. Mais do que isso, o funcionamento do FGP tal como previsto na Lei $\mathrm{n}^{\circ} 11.079 / 04$ pressupõe uma releitura do Direito Administrativo, que tende a assumir uma interpretação mais voltada para a consecução das finalidades públicas em contraposição ao rigor hermenêutico que acaba por engessar a atividade estatal.

Filiando-nos à concepção finalística do Direito Administrativo, entendemos que o FGP possui natureza pública, o que não torna inviável o seu mecanismo de funcionamento conforme previsto na Lei das PPPs. Assim, consideramos inconstitucional parte do parágrafo $1^{\circ}$ do artigo 16, bem como possível a oneração dos bens públicos dominicais que integrarão o Fundo e, em conseqüência, a sua penhorabilidade.

Não obstante, o sucesso das parcerias dependerá de como o novo instituto será conduzido pela Administração Pública e pelo Poder Judiciário, quando provocado para solucionar conflitos oriundos de contratos de PPP. De fato, espera-se que Lei $\mathrm{n}^{0}$ 11.079/04 seja aplicada de modo a proporcionar resultados significativos para a coletividade, com o implemento de projetos de infra-estrutura que busquem o desenvolvimento econômico do País e sempre com respeito à ordem jurídica vigente. 


\section{Referências Bibliográficas}

1 BANDEIRA DE MELLO, Celso Antônio. Curso de Direito Administrativo. $17^{\mathrm{a}}$ edição. Ed.Malheiros, 2004.

2 CARvalho FilHO, José dos Santos. Manual de Direito Administrativo. 13 $3^{\mathrm{a}}$ edição. Ed. Lumen Juris, 2005.

3 DA SILVA, José Afonso. Curso de Direito Constitucional Positivo. $22^{\mathrm{a}}$ edição, Ed. Malheiros, 2003.

4 DI PIETRO, Maria Sylvia Zanella. Parcerias na Administração Pública. $4^{\text {a }}$ edição. Ed. Atlas, 2002.

5 DI PIETRO, Maria Sylvia Zanella. Direito Administrativo. 14 edição. Ed. Atlas, 2002.

6 FAGUNDES, M. Seabra. O Controle dos Atos Administrativos pelo

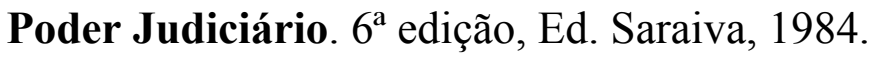

7 FERRAZ, Luciano. Apontamentos sobre Parcerias PúblicoPrivadas. In Revista Interesse Público no 27, 2004, p. 55-59.

8 GASPARINI, Diógenes. Direito Administrativo. $5^{\mathrm{a}}$ edição, Ed. Saraiva, 2000.

9 GRAU, Eros Roberto. A Ordem Econômica na Constituição de 1988. $3^{\text {a }}$ edição, Ed. Malheiros, 1997.

10 HARADA, Kiyoshi. Inconstitucionalidade do Fundo Garantidor das Parcerias Público-Privadas. Art. $8^{\circ}$ da Lei $\mathbf{n}^{0} \mathbf{1 1 . 0 7 9 / 0 4}$. Jus Navegandi, Teresina, a. 9, $\mathrm{n}^{\mathrm{o}}$ 597, 25 fev. 2005. Disponível em: http://www1.jus.com.br/pecas/texto.asp?id=615 
11 HARADA, Kiyoshi. Parcerias Público-Privadas - PPP. In Boletim de Direito Administrativo $\mathrm{n}^{\circ} 2$, 2005, p. 180-182.

12 JACOBY FERNANDES, Jorge Ulisses. Vade-Mécum de Licitações e Contratos. Ed. Fórum, 2004.

13 JUSTEN FILHO, Marçal. Curso de Direito Administrativo. Ed. Saraiva, 2005.

14 LOPES, Pedro C. Raposo. Público e Privado. PPP é nova modalidade de concessão de serviços públicos. Consultor Jurídico, 12 jan. 2005. Disponível em: http://conjur.uol.com.br/textos/251868/

15 MEIRELlES, Hely Lopes. Direito Administrativo Brasileiro. $28^{\text {a }}$ Edição, Ed. Malheiros, 2005.

16 MOREIRA NETO, Diogo de Figueiredo. Curso de Direito Administrativo. 14 ${ }^{\mathrm{a}}$ Edição, Ed. Forense, 2005.

17 MUKAI, Toshio. Parceria Público-Privada. Solução para Grandes Projetos Públicos Municipais. In Fórum de Direito Urbano e Ambiental, $\mathrm{n}^{\mathrm{o}}$ 13, 2004, p. 1.352-1.353.

18 NÓBREGA, Airton Rocha. Parcerias Público-Privadas. Mais Uma Inútil Proposição Legislativa? In Boletim de Direito Administrativo $\mathrm{n}^{\mathrm{o}}$ 7, 2004, p. 1.136-1.139.

19 POLTRONIERI, Renato. Parcerias Público Privadas e a Atuação Administrativa. Ed. Juarez de Oliveira, 2005.

20 SARFERT, Thereza Maria. Técnicas de Privatização. A experiência brasileira. In Revista de Direito Mercantil, Industrial, Econômico e Financeiro 117/00, Ed. Malheiros, p. 182-278. 